Universidade de Brasília

Faculdade de Economia, Administração, Contabilidade e Ciências da Informação e Documentação

\title{
DEPARTAMENTO DE ADMINISTRAÇÃO
}

TRABALHO DE CONCLUSÃO DE CURSO

\section{A IMPORTÂNCIA DA GESTÃO AMBIENTAL NA PERSPECTIVA DE ALUNOS DE ADMINISTRAÇÃO}

\section{AMADEUS KARI DA SILVA}

Brasília - DF

Junho / 2009 
Universidade de Brasília

Faculdade de Economia, Administração, Contabilidade e Ciências da Informação e Documentação

\author{
DEPARTAMENTO DE ADMINISTRAÇÃO
}

TRABALHO DE CONCLUSÃO DE CURSO

A IMPORTÂNCIA DA GESTÃO AMBIENTAL NA PERSPECTIVAS DE
ALUNOS DE ADMINISTRAÇÃO

AMADEUS KARI DA SILVA

Professor Orientador:

\title{
Tomas de Aquino Guimarães - Doutor em Sociologia
}

"Trabalho apresentado em cumprimento às exigências acadêmicas parciais da disciplina Estágio Supervisionado em administração para a obtenção do grau de Administrador"

Brasília - DF

Junho / 2009 
Kari da Silva, Amadeus.

A importância da gestão ambiental na perspectivas de alunos de administração/ Amadeus Kari da Silva. - Brasília, 2009.

$49 \mathrm{f}$. : il.

Monografia (especialização) - Universidade de Brasília, Departamento de Administração, 2009.

Orientador: Tomas de Aquino Guimarães, Dr.

1. Gestão Ambiental. 2. Sustentabilidade. 3. Sistema de Gestão Ambiental. I. Título. 
Universidade de Brasília

Faculdade de Economia, Administração, Contabilidade e Ciências da Informação e Documentação

DEPARTAMENTO DE ADMINISTRAÇÃO

\section{A IMPORTÂNCIA DA GESTÃO AMBIENTAL NA PERSPECTIVAS DE ALUNOS DE ADMINISTRAÇÃO}

A Comissão Examinadora, abaixo identificada, aprova o Trabalho de Conclusão do Curso de Administração da Universidade de Brasília do aluno

\section{AMADEUS KARI DA SILVA}

Tomas de Aquino Guimarães, Doutor em

Sociologia

Professor-Orientador

Luciene Braz,

Professor-Examinador

Brasília, 15 de julho de 2009 
Dedico o meu trabalho a minha família por tem me apoiado e me ajudado em momentos de dificuldade ao longo de todo o curso de graduação. 
Agradeço a todos que de alguma forma contribuíram para minha formação acadêmica: Prof. Tomas de Aquino, AD\&M Consultoria Empresarial, colegas e professores. 
"Os problemas que temos hoje não podem ser resolvidos se mantivermos a mesma maneira de pensar que tínhamos quando os criamos."

\section{Albert Einstein}




\section{RESUMO}

O objetivo desta pesquisa é analisar a importância atribuída por alunos de graduação em administração acerca da gestão ambiental. O referencial teórico baseou-se nos conceitos de Barbieri (2008), Donaire (1994), Tachizawa (2000), Krieger et. al. (2006) entre outros. A metodologia da pesquisa teve como base um questionário elaborado por Costa; Oliveira; Cavalcante; Muzzio (2008). A coleta de dados foi realizada por meio destes questionários junto a 78 estudantes de administração, diurno e noturno, em fase de conclusão de curso da Universidade de Brasília - UnB. Os dados foram analisas por meio de análises estatísticas (média, desvio-padrão e freqüências relativa e absoluta). Estas análises foram aplicadas em três temas de principais: importância do conhecimento em gestão ambiental para os pesquisados; importância do curso de administração para a formação em gestão ambiental; intenções futuras dos pesquisados quanto a atuação com gestão ambiental. Os resultados da pesquisa demonstraram que os alunos atribuem grande importância para o tema de gestão ambiental e veem o curso de administração como grande formador neste tema. Porém as intenções de envolvimento futuro por parte dos pesquisados com o tema é pequeno. Os resultados obtidos são relevantes visto que atualmente a curso de administração não oferece nenhuma disciplina volta especificamente para o tema, demonstrando que os alunos atribuem um nível alto de importância ao tema sem nem mesmo terem uma disciplina na matriz curricular.

Palavras-chaves: Gestão ambiental; Sistema de Gestão ambiental; Sustentabilidade 


\section{SUMÁRIO}

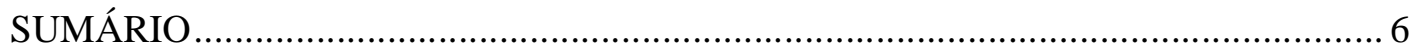

1. INTRODUÇÃ

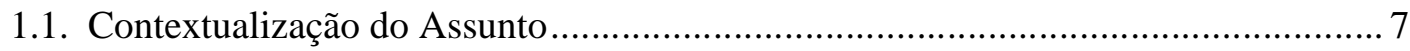

1.2. Descrição da situação problemática .................................................................. 9

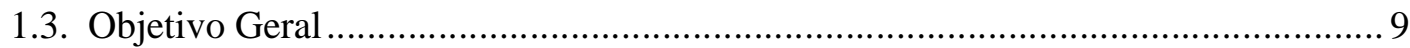

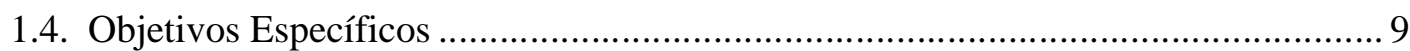

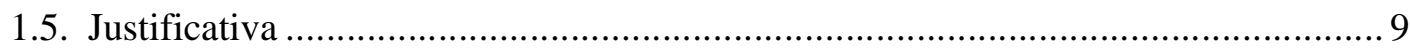

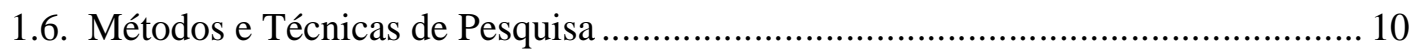

1.7. Estrutura e Organização do Trabalho ...................................................................... 10

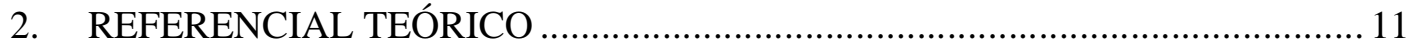

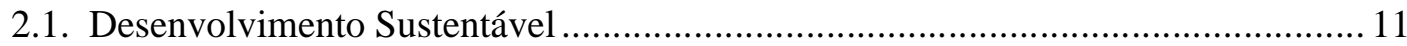

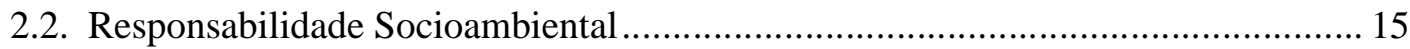

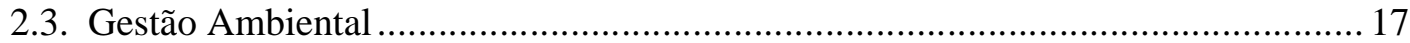

2.3.1. Sistema de Gerenciamento Ambiental....................................................... 23

2.3.2. Benefícios da Gestão Ambiental ................................................................... 25

2.4. Estudos Relevantes a respeito de percepção da gestão ambiental no curso de

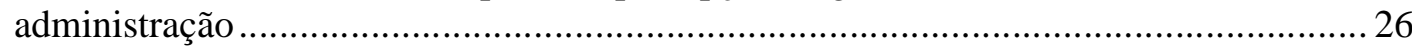

3. MÉTODOS E TÉCNICAS DE PESQUISA.................................................... 28

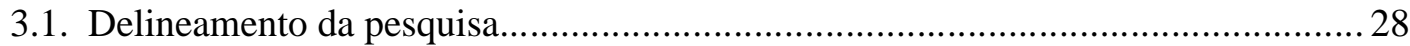

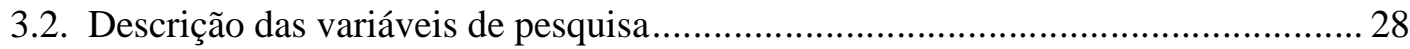

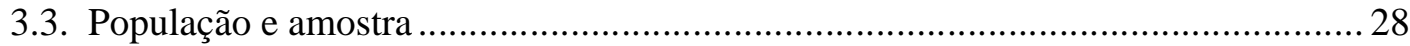

3.4. Procedimentos e instrumentos utilizados na coleta e análise dos dados ................ 29

3.5. Comentários sobre o processo da coleta de dados ............................................... 30

4. APRESENTAÇÃO E ANÁLISE DOS RESULTADOS DA PESQUISA .............. 31

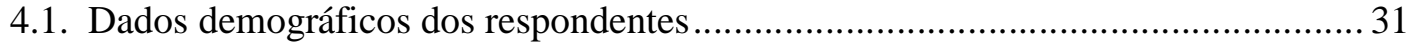

4.2. Experiência profissional e área de interesse dos respondentes .............................. 32

4.3. Percepção dos respondentes quanto à gestão ambiental ...................................... 36

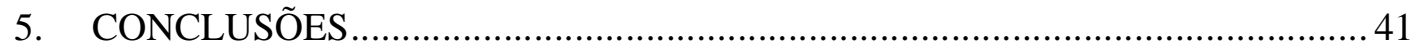




\section{INTRODUÇÃO}

\subsection{Contextualização do Assunto}

Um novo desafio se impõe à sociedade atual: o gerenciamento dos recursos naturais que sabidamente são esgotáveis. A preocupação com o meio ambiente tem sido uma reivindicação da sociedade moderna em função de sua relevância para a qualidade de vida da população em geral. Assim, um novo desafio é posto para o modelo de administração. Face a expansão da consciência coletiva com relação ao meio ambiente novas demandas sociais e ambientais são repassadas da comunidade para as organização o que induz a um novo posicionamento por parte dos gestores e diante destas demandas (TACHIZAWA, 2008).

Em decorrência de tantas mudanças e pressão sobre o meio ambiente, surge na administração, na década de 60, a Teoria da Contingência que nega o modelo de best way (melhor maneira) da Escola Clássica e apóia-se no movimento das Relações Humanas. A teoria da contingência afirma que a estrutura e o comportamento de uma organização dependem de diversas variáveis situacionais tais com: ambientais, tecnológicas e tamanho da organização; possibilitando assim que uma organização venha a ter comportamentos diferentes dependendo da situação. Desta maneira o the best way (a melhor maneira) é subistituido pelo one best way (uma melhor maneira) (TACHIZAWA, 2008, p. 24-25).

A partir do surgimento da variável ambiental no contexto mundial organizacional, as primeiras tentativas de combater o aceleramento da degradação ambiental foram: diminuição da poluição; controle ambiental e integração do controle na gestão administrativa. Um enfoque mais recente da questão ambiental é o da abordagem com uma visão sistêmica e holística nas organizações. Desta forma, esta integra o sistema de qualidade e de gerenciamento ambiental (ALMEIDA, 2007).

Assim, a discussão sobre desenvolvimento sustentável e gestão ambiental ganha força. Tendo em vista que a quantidade de recursos naturais necessários para manter o nível de produção e desenvolvimento do planeta torna-se limitada. Com todos os danos causados ao meio-ambiente e a ineficiência de políticas e medidas globais para a sua redução, torna-se necessário a criação por parte das organizações e das políticas públicas de ações para mitigar e minimizar tais efeitos danosos. Ações como: responsabilidade socioambiental, desenvolvimento sustentável e gestão ambiental. 
Desta maneira as organizações viram-se obrigadas a integrar em sua administração a variável ambiental, e não apenas em atitudes, atividades e processos, mas também nas decisões da alta cúpula administrativa. Na atual conjuntura, não basta atender as necessidades atuais e gerar respostas setoriais e estanques. É necessário planejamento e uma análise das necessidades e problemas futuros. Assim, os profissionais que irão desempenhar tal função devem estar muito bem preparados (DONAIRE ,2004).

Com a nova abordagem da variável ambiental nas organizações, percebe-se que a mesma está além da administração tradicional, pois esta variável é interdisciplinar e multifacetada. Desta maneira o gerenciamento da variável ambiental tende a ser custoso, pois, além de seu caráter próprio de administração de demandas que inevitavelmente geram conflitos (políticos e econômicos, principalmente) esta variável exige habilidades para lidar com ambigüidades, próprias do pensamento em redes e não em hierarquias, que são atitudes pouco desenvolvidas nos gerentes convencionais (ALMEIDA, 2007).

Logo, as organizações que se interessarem em solucionar seu envolvimento com a variável ambiental, devem acrescer em seu planejamento estratégico e operacional um sistema de gestão ambiental adequado que possibilite o alinhamento dos objetivos ambientais com os objetivos organizacionais. Isto faz com que a gestão ambiental seja "contemplada na estrutura organizacional, interferindo no planejamento estratégico," desta maneira a gestão ambiental "passou a ser uma atividade importante na organização da empresa, seja no desenvolvimento das atividades de rotina, seja nas discussões dos cenários alternativos e a conseqüente análise de sua evolução, gerando políticas, metas e planos de ação" (DONAIRE, 2004, p. 37).

As organizações preocupadas com o meio ambiente têm a tendência de se destacar perante seus stakeholders já que a questão ambiental se tornou um diferencial competitivo (FERREIRA; FERREIRA, 2008). Ainda segundo Ferreira e Ferreira (2002),

\footnotetext{
é preeminente que alunos dos cursos de graduação em Administração de Empresas tenham presentes em seus currículos disciplinas relacionadas à gestão ambiental, visto que tais questões são de extrema relevância e que devem, portanto, serem consideradas no debate acadêmico (FERREIRA; FERREIRA, 2002, p. 4).
}

Percebe-se, portanto que a quantidade de competências exigidas de um gestor ambiental é muito grande. Assim, o curso de administração é a porta de saída de profissionais que possivelmente poderão ocupar cargos gerenciais e estratégicos relacionados a variável ambiental. Para tanto os futuros administradores devem estar preparados para assumir e 
desempenhar esta responsabilidade. Mesmo não sendo um gestor, poderá ser um vetor de mudanças paradigmáticas nas organizações.

\subsection{Descrição da situação problemática}

Tendo em vista o exposto que reforça a importância do desenvolvimento sustentável e da gestão ambiental para o contexto atual das organizações e, principalmente, do planeta, percebeu-se a necessidade de analisar a percepção dos futuros administradores formados pela Universidade de Brasília, já que o gestor dessa nova variável será uma profissão singular no mercado dos próximos anos.

Fundamentando-se nesta idéia, este estudo visa analisar qual é a importância atribuída por alunos de graduação em administração à gestão ambiental?

\subsection{Objetivo Geral}

O objetivo geral deste estudo é analisar a importância atribuída por alunos de graduação em administração acerca da gestão ambiental.

\subsection{Objetivos Específicos}

Para a análise do objetivo geral exposto, são necessários os seguintes objetivos específicos:

- Analisar o grau de conhecimento de alunos de administração sobre o tema gestão ambiental;

- Identificar a atribuição de importância para os alunos da gestão ambiental no curso de administração;

- Diagnosticar a importância para os alunos da prática em gestão ambiental;

- Verificar o interesse dos alunos em atuar nesta área, após a conclusão do curso;

\subsection{Justificativa}

A gestão ambiental e o desenvolvimento sustentável estão, cada vez mais, tornandose indispensáveis para as organizações públicas e, principalmente, privadas, devido a pressões socais, ambientais, governamentais e mercadológicas, além disso, no setor privado, a gestão ambiental e o desenvolvimento sustentável tornarem-se um diferencial competitivo em um 
mercado, muitas vezes, lotado de concorrentes, sejam eles físicos ou "virtuais" (empresa constituída somente por um website, sem estrutura física real).

Ainda que a profissão de "gestor ambiental" não esteja em voga, ela deverá ser nos próximos anos uma importante ocupação para os profissionais de administração, como relata a pesquisa da Profuturo/FIA (WRIGHT et. al., 2009), que aponta a carreira de "gerente de eco-relações" como uma das mais promissoras para os próximos 10 anos.

Desta forma, o estudo visa compreender como os futuros gestores abordam este conhecimento tão importante e ascendente, em um mercado cada vez mais competitivo e escasso de ofertas de trabalhos. Acresenta-se a isto o fato de o estudo se realizar na capital do país onde está concentrada a maioria do poder público, o que faz com que exista a possibilidade de muitos gestores trabalhem em organizações públicas.

\subsection{Métodos e Técnicas de Pesquisa}

Serão aplicados questionários com perguntas fechadas. A análise será realizada por meio de software especializado além de métodos estatísticos.

\subsection{Estrutura e Organização do Trabalho}

A estrutura do trabalho está dividida em quatro capítulos principais, a saber:

1. Revisão das principais teorias e conceitos sobre os principais constructos;

2. Metodologia para alcance dos objetivos apresentados neste estudo;

3. Coleta e analise dos dados obtidos através da aplicação de questionários com os alunos de administração.

4. Conclusões sobre as análises. 


\section{REFERENCIAL TEÓRICO}

\subsection{Desenvolvimento Sustentável}

A continuidade do processo de desenvolvimento e expansão das economias mundiais tem sido motivo de discussão por administradores e gestores, ainda mais após a recente crise dos derivativos americanos. Nesse sentido é necessário trabalhar o conceito de desenvolvimento em uma perspectiva mais ampla que relacione a questão da qualidade de vida e de seus determinantes, quer sejam estes culturais, econômicos, políticos, sociais e até mesmo individuais (KEINERT; KURRUZ, 2002). Logo o debate acerca do desenvolvimento sustentável nos cursos de administração é importante para que os futuros administradores passam vir a ser gestores e co-autores no processo de mudança do pensamento paradigmático existente entre desenvolvimento e sustentabilidade (KHOR, [S.d]).

As primeiras manifestações acerca de sustentabilidade remontam de 1972 com um relatório de economista e pensadores denominado "Os limites para o crescimento". E, por conseguinte, muitos outros estudos relatórios e análises foram publicados, tais como: Mankind at Turning Point e Reshaping the International Order. Todavia, a primeira vez que o conceito de sustentabilidade apareceu foi em 1987, no documento da ONU, "Relatório Brundtland - Nosso Futuro Comum".

Após esta iniciativa pioneira começaram a surgir iniciativas coletivas e organizadas internacionalmente visando debater e propor medidas para os recentes problemas ambientais, algumas das iniciativas foram:

- Conferência das Nações Unidas sobre o Ambiente Humano (Estocolmo 1972);

- Seminário sobre Estratégia e Desenvolvimento e Meio Ambiente e Padrões de uso de Recursos (México 1974);

- Protocolo de Montreal (Canadá 1987);

- Eco 92 (Brasil 1992);

- Convenção das Nações Unidas sobre Mudanças Climáticas (Japão 1997);

A preocupação com o desenvolvimento sustentável vem crescendo ano a ano em escala mundial, devido às mudanças climáticas ocorridas no planeta e à pressão político-social de grupos civis organizados. Para Sachs $(1993,2004)$, o desenvolvimento exige um forte 
equilíbrio entre cinco dimensões diferentes (sustentabilidades: social, ambiental, econômica,espacial e cultural) e exige também que se evite a competitividade espúria e, em ultima instância, autodestrutiva, baseando-se na depreciação da força de trabalho e dos recursos naturais. O mesmo autor considera 5 pilares para o desenvolvimento sustentável, quais sejam:

a)Social, fundamental por motivos tanto intrínseco quanto instrumentais, por causa da perspectiva de disrupção social que paira de forma ameaçadora sobre muitos lugares problemáticos do nosso planeta; b)Ambiental, com as duas dimensões (os sistemas de sustentação da vida como provedores de recursos e como "recipientes"para a disposição de resíduos); c)Territorial, relacionada à distribuição espacial dos recursos, das populações e das atividades; d)Econômico, sendo a viabilidade econômica a conditio sine qua non para que as coisas aconteçam; e)Político, a governança democrática é um valor fundador e um instrumento necessário para fazer as coisas acontecerem; a liberdade faz a diferença.1 (SACHS, 2004, p. 15-16)

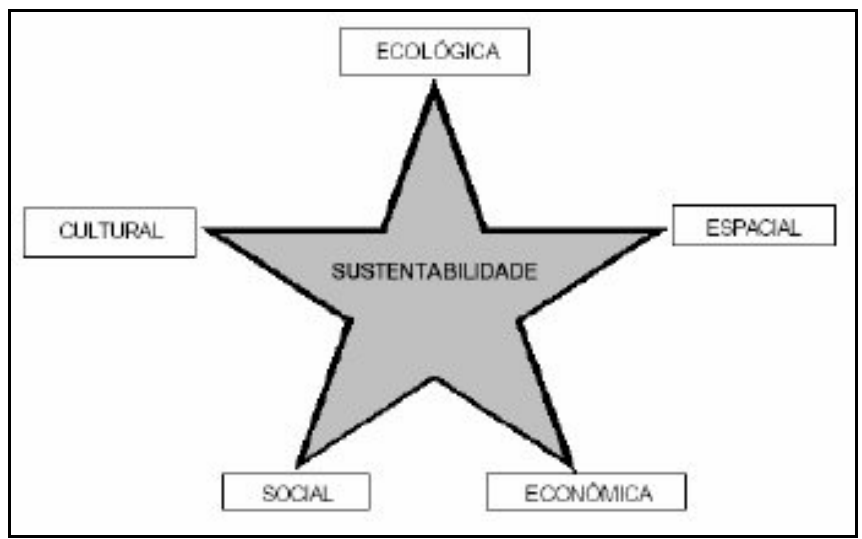

Figura2.1 - As cinco dimensões da sustentabilidade

Fonte: Sachs apud Campos( 2004)

Para a Comissão Mundial de Desenvolvimento e Meio ambiente das Nações Unidas ONU a definição de desenvolvimento sustentável "é suprir as necessidades da população mundial atual sem comprometer as necessidades das populações futuras”. Percebe-se que a definição da ONU aponta para uma preocupação com a população mundial, tendo em vista que a sua missão é focada em todas as dimensões citadas por Sachs para a melhoria da vida no planeta Terra.

Menegat e Almeida et. al, (2004), abordam o desenvolvimento sustentável em uma cidade de forma matricial na qual dois eixos à formam: 
- Eixo simbiótico: onde o governo e os cidadãos criam uma tensão para as mudanças ocorrerem e os agentes ( governo e cidadãos) não são forças isoladas e dependem um do outro para que o processo de mudanças ocorra.

- Eixo autopoiético: onde a estabilidade e a mudança criam a tensão, que se caracteriza por manter a estabilidade social ou iniciar a mudança cultural.

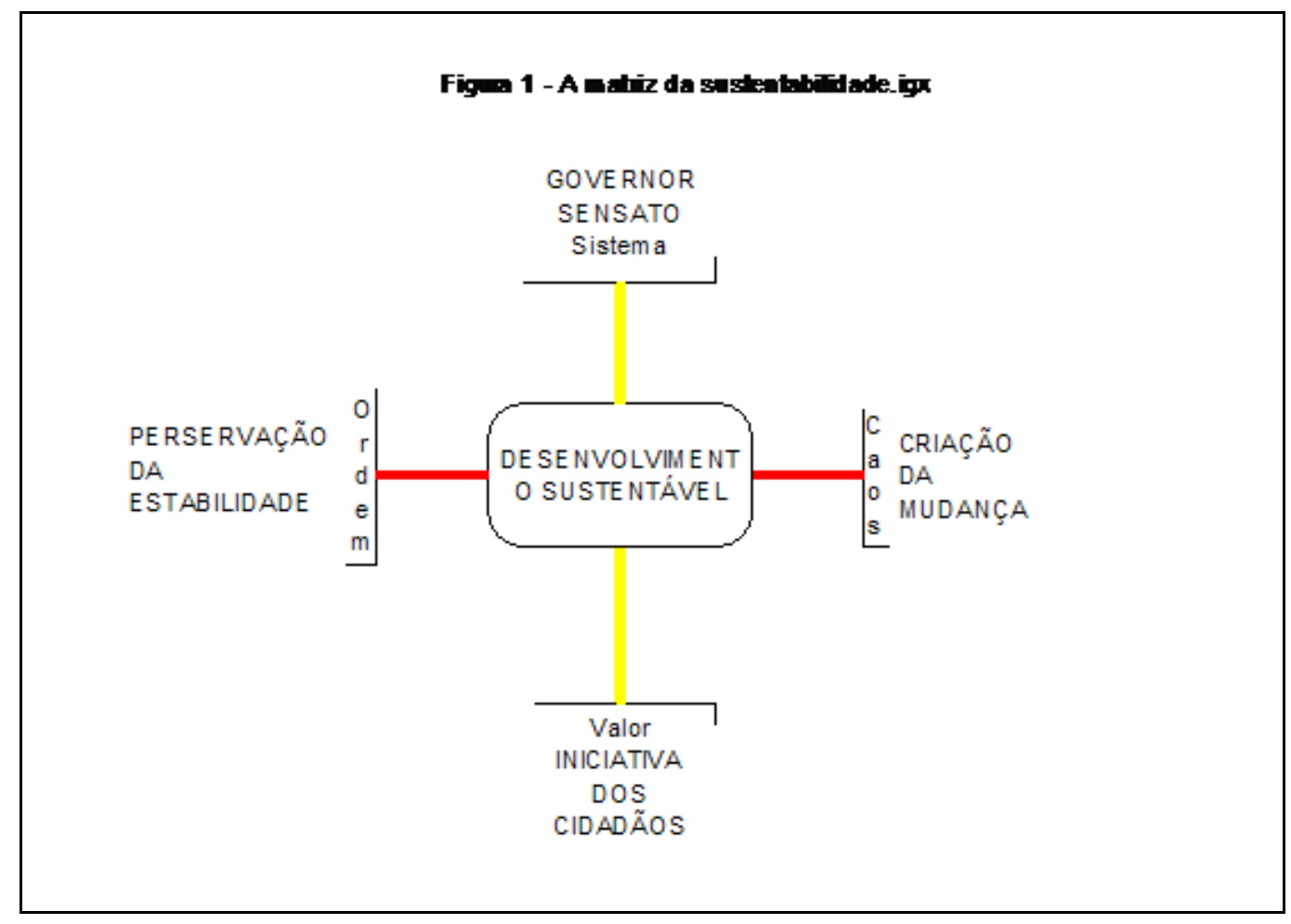

\section{Figura2.2 - A matriz da sustentabilidade}

Fonte: Menegat e Almeida (et. al, 2004)

Desta maneira quando os cidadãos têm iniciativas e o governo cria legislações que apóiem e incentivem essas iniciativas, a mudança cultural acaba por causar perturbações no sistema. Caso isso não ocorra a estabilidade social é o fruto da estrutura que irá manter-se (MENEGAT; ALMEIDA et. al, 2004).

Segundo Krieger (et. al., 2006) o termo desenvolvimento sustentável é a "utilização equilibrada dos recursos naturais, considerando a satisfação das necessidades e do bem-estar da presente geração e o interesse de gerações futuras” (KRIEGER, et. al., 2004). 
Conceitos sobre sustentabilidade são colocados de forma diferente de acordo com o vertente de pesquisa e formação do autor. Soma-se a isso o fato de não haver um consenso sobre o conceito de desenvolvimento sustentável, como falta também uma discussão crítica sobre a real efetividade das medidas necessárias para alcançar o desenvolvimento sustentável (VAN BELLEN, 2004). O mesmo autor em sua pesquisa, com especialistas em desenvolvimento, descreve as 3 ferramentas mais citadas, pelos especialistas, para mensurar o desenvolvimento sustentável.

Uma das a ferramentas, citadas na pesquisa é a Ecological Foorprint Method (Metodo da pegada ecológica) desenvolvida por Wackernagel e Rees (Our Ecological Footprint,1996),foi elaborada mediante uma conceituação de desenvolvimento sustentável, desenvolvida pelos autores. Segundo Wackernagel e Rees (apud. Van Bellen, 2004) a confusão existente acerca do conceito de desenvolvimento sustentável não é totalmente inocente, pois de alguma forma, para os autores, esta profunda discussão reflete os conflitos de interesses existentes sobre o tema:

\begin{abstract}
A interpretação dos autores para a definição de desenvolvimento sustentável encontrada no Relatório Brundtland é que o imperativo econômico convencional, maximização da produção econômica, deve ser restringido em favor dos imperativos sociais (minimização do sofrimento humano A interpretação dos autores para a definição de desenvolvimento sustentável encontrada no Relatório Brundtland é que o imperativo econômico convencional, maximização da produção econômica, deve ser restringido em atual e futuro) e ecológicos (de proteção da ecosfera). O desenvolvimento sustentável depende então de reduzir a destruição ecológica, principalmente através da diminuição das trocas de energia e matéria-prima dentro da economia. Neste sentido, a sustentabilidade para os autores se assemelha à proposta do Material Inputs per Service, MIPS, de desmaterialização da economia e do aumento da qualidade de vida, principalmente para a maioria mais pobre do mundo. Pela primeira vez o meio ambiente e a eqüidade se tornam fatores explícitos dentro da questão do desenvolvimento. (WACKERNAGEL; REES apud. VAN BELLEN, 2004, p. 7)
\end{abstract}

A segunda ferramenta apresentada por Van Bellen (2004) é o Dashboard of Sustainability (painel da sustentabilidade), desenvolvida pelo Consultative Group on Sustainable Development Indicators - CGSDI. Para Hardi (apud. VAN BELLEN, 2004) a maior dificuldade para se avaliar a sustentabilidade é:

o desafio de explorar e analisar um sistema holístico. Para este autor, uma visão holística não requer apenas uma visão dos, por si só complexos, sistemas econômico, social e ecológico, mas também a interação entre estes sistemas. Estas 
interações normalmente amplificam a complexidade das questões, criando obstáculos para aqueles que estão preocupados em gerenciar ou avaliar os sistemas. As tentativas para capturar esta complexidade são geralmente consideradas essenciais e os sistemas são normalmente agrupados de acordo com a extensão do sucesso em alcançar toda esta complexidade (HARDI, apud. Van Bellen, 2004, p. 12).

Boechat e Bruzzi e Filho (2005) percebem o mesmo que Wackernagel e Rees (1996). Em sua pesquisa com empresas brasileiras que adotam a sustentabilidade, mostrou que não existe ainda um conceito de sustentabilidade unificado entre elas. Mesmo a maioria delas declarando que assumem o conceito formal percebeu-se que o conceito de sustentabilidade, muitas vezes, é vinculado ao de Triple Bottom Line (resultados econômicos, sociais e ambientais), ou ao de stakeholders e ainda somente a aspectos financeiros e à longevidade da própria empresa. Desta forma nenhuma empresa estabeleceu conexão do seu conceito de sustentabilidade exclusivamente com o meio ambiente e ainda segundo os autores "a falta de uma definição clara e uniforme é um sinal inequívoco de uma deficiência que dificulta o estabelecimento da gestão da sustentabilidade" (BOEACHAT; BRUZZI; FILHO, 2005, p. 16).

O conceito apresentado por Soares (apud SOARES 2006, p. 8) de sustentabilidade decorre do conceito de organizações conscientes que seria:

Organizações Conscientes, trata basicamente da tendência de as organizações perceberem a vida e seu entorno, reconhecendo que seu principal objetivo é o atendimento às demandas humanas, entre elas o lucro (em contraponto à concepção de que essa é a finalidade única da empresa). Elas também reconhecem os padrões vitais que garantem a longevidade de organismos e tentam gerir sua existência de forma coerente com essas percepções, em um processo inclusivo de suas redes de interações, considerando-se aí indivíduos e organizações (SOARES (apud. Filho 2006, p.8).

Assim, percebe-se que a excessiva preocupação com lucros, resultados financeiros e as partes interessadas, faz com que as organizações percam a noção de que estão dentro de um sistema maior de sustentabilidade, como exemplificado pelo conceito de organizações conscientes. Essas questões são explorados a seguir.

\subsection{Responsabilidade Socioambiental}

A responsabilidade social hoje está crescendo entre as empresas brasileiras e de certa forma, vem sendo trabalhada para expor à sociedade as beneficies que as organizações trazem 
a ela ou ainda por projetos e estudos que as empresas realizam tendo como foco a responsabilidade social.

Para Donaire (1999), a responsabilidade social implica em uma série de obrigações da empresa para com a sociedade. Estas obrigações podem ser projetos filantrópicos e educacionais, planejamento da comunidade, equidade nas oportunidades de emprego, serviços sociais em geral e proteção ambiental. Essas "responsabilidades" adquiridas pelas empresas advêm de um contrato social firmado entre sociedade e empresa. Onde a sociedade permite a existência e o trabalho por um objetivo legítimo das organizações e em troca "cobra" a contribuição desta para a sociedade. Nos dias atuais as requisições sociais mudam, dependendo do contexto, e não mais é aceito o simples progresso social.

Corroborando com esse pensamento Carrol (apud DONAIRE, 1999) considera responsabilidade social como,"a responsabilidade social das organizações diz respeito às expectativas econômicas, legais, éticas e sociais que a sociedade espera que as empresa atendam, num determinado período de tempo"(CARROL apud DONAIRE, 1999, p. 22).

Segundo a Fundação para o Prêmio Nacional da Qualidade (FNPQ) (2001) são cinco os estágios que uma empresa deve percorrer até chegar a exercer a fase avançada de responsabilidade social.

\begin{tabular}{|l|l|}
\hline Estágios & Descrição \\
\hline Estágio 1 & $\begin{array}{l}\text { A organização não assume responsabilidade perante a sociedade e } \\
\text { não toma ações em relação ao exercício da cidadania. Não há } \\
\text { promoção do comportamento ético. }\end{array}$ \\
\hline Estágio 2 & $\begin{array}{l}\text { A organização reconhece os impactos causados por seus produtos, } \\
\text { processos e instalações, apresentando algumas ações isoladas, no } \\
\text { sentido de minimizá-los. Evidentemente, busca promover o } \\
\text { comportamento ético. }\end{array}$ \\
\hline Estágio 3 & $\begin{array}{l}\text { A organização está iniciando a sistematização de um processo de } \\
\text { avaliação dos impactos de sues produtos, processos e instalações e } \\
\text { exerce alguma liderança em questões de interesse da comunidade. } \\
\text { Existe envolvimento das pessoas em esforços de desenvolvimento } \\
\text { social. }\end{array}$ \\
\hline Estágio 4 & $\begin{array}{l}\text { O processo de avaliação dos impactos dos produtos, processos e } \\
\text { instalações está em fase de sistematização. A organização exerce } \\
\text { liderança em questões de interesse da comunidade de diversas } \\
\text { formas. O envolvimento das pessoas em esforços de } \\
\text { desenvolvimento social é freqüente. A organização promove o } \\
\text { comportamento ético. }\end{array}$ \\
\hline
\end{tabular}




\begin{tabular}{|l|l|}
\hline & $\begin{array}{l}\mid \\
\text { O processo de avaliação dos impactos dos produtos, processos e } \\
\text { instalações está sistematizado, buscando antecipar as questões } \\
\text { Eúblicas. A organização lidera questões de interesse da } \\
\text { comunidade e do setor. O estímulo à participação de pessoas e em } \\
\text { esforços de desenvolvimento social é sistemático. Existem formas } \\
\text { implementadas de avaliação melhoria da atuação da organização } \\
\text { no exercício da cidadania e no tratamento de suas } \\
\text { responsabilidade públicas. }\end{array}$ \\
\hline
\end{tabular}

\section{Figura 2.3 - Estágios de Responsabilidade Social}

Fonte: FNPQ apud. Tachizawa (2008), com adaptações.

Atualmente com a difusão e facilidade de acesso as informações e a crescente conscientização do consumidor faz com que este tenha uma postura rígida, voltada à interagir com organizações que sejam éticas, com boa imagem no mercado e que atuem de forma ecologicamente correta.

Todavia a responsabilidade social empresarial (social ou ambiental) muitas vezes é descriminada e mal interpretada devido à falta de conhecimento de gestores e sociedade e também pela escassez de estudos científicos nesta área. Muitas vezes são confundidas com doação ou filantropia e não é vista pela sociedade com um benefício e nem para os gestores (PORTE;KREMER, 2006) como um investimento, que gera vantagem competitiva.

\subsection{Gestão Ambiental}

Ao longo dos anos a preocupação com a variável ambiental nas organizações cresceu e a gestão desta teve que ser aprimorada e incorporada em todas as unidades da empresa. A evolução da gestão ambiental ou gerenciamento ambiental ocorre até hoje e cada vez mais é considera nas decisões estratégicas das organizações.

No Brasil o tema de gestão ambiental começa a ser discutido nos anos 1990, com um crescente aumento na produção científica acerca do tema, acompanhando o crescimento internacional, que foi marcado pelo lançamento de trabalhos clássicos como, o de Buchoolz (1998), Hunt e Auster (1990) e Hart (1995), como mencionado por JABBOUR; SANTOS; BARBIERI (2008). Danaire (1994) foi um dos primeiros autores a publicar sobre o tema no Brasil, e seu artigo tratava da internalização e aceitação da variável ambiental nas empresas brasileiras e como conclusão percebeu que a preocupação das empresas com a nova variável era irreversível e que não se tratava de simples copia das organizações internacionais. E ainda 
salientou que as empresas que melhor concebessem essa nova realidade seriam tratadas de forma diferenciada pelo mercado.

Concomitantemente começa a se organizar os primeiros encontros para discussão e abordagem do tema no Brasil, como o Encontro Nacional de Gestão Empresarial e Meio Ambiente (ENGEMA), que reuni os periódicos sobre o tema, com ocorrência bianual e que hoje está em sua décima edição.

Segunda a Constituição da República Federativa do Brasil de 1988 em seu artigo 225 define: "Todos têm direito ao meio ambiente ecologicamente equilibrado, bem de uso comum do povo e essencial à sadia qualidade de vida, impondo-se ao poder público e à coletividade o dever de defendê-lo preservá-lo para as presentes e futuras gerações." Desta forma a Constituição Brasileira proporciona uma idéia genérica do termo de responsabilidade ambiental no Brasil.

A definição de impacto ambiental, que é a base para a criação de políticas de gestão ambiental, e que norteia as ações do Conselho Nacional do Meio Ambiente - CONAMA é:

Considera-se impacto ambiental qualquer alteração das propriedades físicas, químicas e biológicas do meio ambiente, causada por qualquer forma de matéria ou energia resultante das atividades humanas, que direta ou indiretamente, afetam-se: a saúde, a segurança e o bem-estar da população; as atividades sociais e econômicas; a biota; as condições estéticas e sanitárias do meio ambiente e a qualidade dos recursos naturais (CONAMA, 1986)

Segunda a Procuradoria Geral da República - PGR, por meio de seu Programa de gestão ambiental define:

A gestão ambiental (GA) é uma prática muito recente, que vem ganhando espaço nas instituições públicas e privadas. Através dela é possível a mobilização das organizações para se adequar à promoção de um meio ambiente ecologicamente equilibrado. Seu objetivo é a busca de melhoria constante dos produtos, serviços e ambiente de trabalho, em toda organização, levando-se em conta o fator ambiental. Atualmente ela começa a ser encarada como um assunto estratégico, porque além de estimular a qualidade ambiental também possibilita a redução de custos diretos (redução de desperdícios com água, energia e matérias-primas) e indiretos (por exemplo, indenizações por danos ambientais) (PGR)

Para o Instituto de Desenvolvimento Gerencial - INDG a gestão ambiental pode ser definida como:

Tomando-se por base o modelo normativo NBR ISO 14001, o Sistema de Gestão Ambiental é definido como a parte do sistema de gestão da organização que inclui estrutura organizacional, atividades de planejamento, responsabilidades, práticas, procedimentos, processos e recursos para desenvolver, implementar, atingir, analisar criticamente e manter a sua Política Ambiental. Como documento de importância 
estratégica, a Política é a declaração formal da organização sobre as intenções e os princípios que regem o seu desempenho ambiental. Deve conter, no mínimo, três compromissos fundamentais: atendimento à legislação e outros requisitos pertinentes, prevenção da poluição e melhoria contínua (INDG)

Com isso a organização deve analisar todas as suas atividades, produtos, serviços e verificar os aspectos ambientais envolvidos para que possa avaliar os reais e potenciais impactos ao meio ambiente. Essa analise permite a empresa priorizar sua atuação em aspectos considerados significativos e assim definir melhor seu gerenciamento (INDG).

Percebe-se que em todos os conceitos apresentados existe um eixo central que é a preocupação com as gerações futuras. Além que de que as empresas, quando citadas, devem assimilar a gestão ambiental em suas atividades e processos para que tenham êxito nesta questão.

Para Krieger et. al. (2006) o conceito de gestão ambiental é "Conjunto de medidas organizacionais, responsabilidades práticas, procedimentos, processos e recursos de uma empresa ou de uma administração pública para a execução de sua política ambiental”. E em outra definição tem-se "Condução, direção e controle do uso de recursos naturais, dos riscos ambientais e das emissões para o meio ambiente, por intermédio da implementação do sistema de gestão ambiental.”. Já a definição de gestão ambiental empresarial dar-se-á como "Conjunto de atividades administrativas e operacionais realizadas pela empresa para abordar problemas ambientais decorrentes de sua atuação e para evitar que ocorram no futuro.” E para gestão ambiental pública tem-se: "Conjunto de atividades administrativas e operacionais realizadas pelo Poder Público, de acordo com uma política ambiental, para abordar problemas ambientais decorrentes de sua atuação e para evitar que ocorram no futuro."

Segundo Maimon (1996), as vantagens para as empresa que adotam o sistema de gestão ambiental podem ser várias, tais como, organizacionais, redutor de custo de operação, minimizar acidentes e competitivas. A gestão ambiental proporciona, através do planejamento organizacional, construir novas alternativas para a empresa torne-se mais competitiva e menos ambientalmente problemática.

Para Maimon (apud. FREY;WITTMANN, 2006):

Grande parte da redução do custo de operação, na gestão ambiental, é obtida a partir da eliminação de resíduos industriais que são gerados por meio de processos ineficientes e da má utilização da matéria-prima que, além de não adicionarem valor ao produto, geram despesas quanto à sua destinação, aumentando inclusive a taxa de risco ambiental (MAIMON apud. FREY;WITTMANN, 2006, p. 101). 
A preocupação central no surgimento do conceito da variável "gestão ambiental" para as empresas era que as mesmas incorporassem em seu dia-a-dia, em suas estratégias, processos e produtos a nova dimensão. Esse desafio, porém não é fácil e nem rápido.

Lerípio (apud FREY; WITTMANN, 2006, p.101) salienta que no processo de implementação do ISSO 14000 há uma oportunidade "para que o empresário, em processo contínuo, identifique oportunidades de melhorias que reduzam os impactos das atividades de sua empresa sobre o meio ambiente, de forma integrada à situação de conquista de mercado e lucratividade".

Andrade, Carvalho e Tachizawa (2000) entendem que as empresas devem ter uma visão holística e sistêmica para enxergar as relações de causa e efeito, tanto logo as interrelações entre os recursos captados, os processos e os valores por elas obtidos. Desta feita "a organização deve ser visualizada como um conjunto de partes em constante interação, constituindo- se em um todo orientado para determinados fins, em permanente relação de interdependência com o ambiente externo" (ANDRADE; CARVALHO; TACHIZAWA, 2000, p. 90).

A definição de gestão ambiental de Bruns [S.d] é:

A Gestão Ambiental visa ordenar as atividades humanas para que estas originem o menor impacto possível sobre o meio. Esta organização vai desde a escolha das melhores técnicas até o cumprimento da legislação e a alocação correta de recursos humanos e financeiros.

O que deve ficar claro é que "gerir" ou "gerenciar" significa saber manejar as ferramentas existentes da melhor forma possível e não necessariamente desenvolver a técnica ou a pesquisa ambiental em si. Pode estar aí o foco da confusão de conceitos entre a enorme gama de profissionais em meio ambiente. Pois, muitos são parte das ferramentas de Gestão (ciências naturais, pesquisas ambientais, sistemas e outros), mas não desenvolvem esta como um todo, esta função pertence aos gestores ou gerentes ambientais que devem ter uma visão holística apurada.

Pode-se então concluir que a Gestão Ambiental é consequiência natural da evolução do pensamento da humanidade em relação à utilização dos recursos naturais de um modo mais sábio, onde se deve retirar apenas o que pode ser reposto ou caso isto não seja possível, deve-se, no mínimo, recuperar a degradação ambiental causada (BRUNS [S.d]).

Donaire (apud CORAZZA, 2003) coloca que a elevada posição hierárquica ocupada pela gestão ambiental, no contexto internacional, pode ser aplicada também no Brasil, pois esta característica é um modo de integração "da gestão ambiental nas organizações que segue 
três fases: percepção, compromisso e ação. Segundo o autor, a cúpula administrativa (ou alta administração da empresa) é a instância responsável pela percepção da "variável ecológica" como importante para a política organizacional" (CORAZZA, 2003, p. 7).

Assim como Sanches (apud CORAZZA, 2003) que corrobora "com a idéia de que o envolvimento da alta administração seja fundamental para o sucesso das iniciativas da empresa com relação à proteção ambiental. Nas fases subseqüentes, de compromisso e ação que podem não ocorrer em todas as organizações (o processo só é completo para aquelas que buscam a "excelência ambiental") - os outros níveis hierárquicos passam a ser envolvidos na integração da gestão ambiental, 'de cima para baixo'"(SANCHES apud. CORAZZA, 2003, p.7)

Barbieri (2004) entende que:

Os termos administração, gestão do meio ambiente, ou simplesmente gestão ambiental serão aqui entendidos como as diretrizes e as atividades administrativas e operacionais, tais como, planejamento, direção, controle, alocação de recursos e outras realizadas com o objetivo de obter efeitos positivos sobre o meio ambiente, quer reduzindo ou eliminando os danos ou problemas causados pelas ações humanas, quer evitando que eles surjam (BERBIERI, 2004)

Fica claro, desta maneira, que o processo da gestão ambiental deve permear toda a organização nas três dimensões da pirâmide organizacional: operacional, tático e estratégico. E concentrar-se ou apoiar-se na alta cúpula da organização, fazendo com que os demais níveis sintam-se à vontade para desenvolver, aplicar e usar as ferramentas de gestão ambiental da empresa. Isto feita possibilita que a empresa tenha êxito no gerenciamento ambiental.

Povos mais desenvolvidos cultural e economicamente, como os europeus, já consideram a questão ambiental como terceira prioridade, atrás apenas do emprego e saúde. Todavia, o foco da gestão ambiental não pode ser o meio ambiental e sim a empresa, pois somente através da melhoria dos seus produtos, processos e serviços conseguirá obter a redução nos impactos ambientais (VITERBO JUNIOR, 1998). Ainda segundo Viterbo Junior (1998, p.51) a definição do construto é "Gestão ambiental, nada mais é do que a forma como uma organização administra as relações entre suas atividades e o meio ambiente que as abriga, observadas as expectativas das partes interessadas"

Crognale (1999) considera que a gestão ambiental está em um estágio mais amadurecido e reconhecida como unidade de negocio consolidada. O que antes costumava ser apenas um padrão regulatório para as empresas seguissem, hoje foi substituído por um 
novo paradigma de ter uma visão holística e incorporar a gestão ambiental em todas as áreas de negócio da organização: a visão holística do gerenciamento ambiental torna-se importante e deve estar presente em todas as unidades de negócios da organização.

Mesmo decorridos 19 anos desde começo do debate acerca da gestão ambiental e da variável meio-ambiente nas organizações, ainda não existe uma conceito formado sobre o tema e alguns conceitos, práticas e ações estão em buscando consolidação teórica de pragmática (COSTA; OLIVEIRA; CAVALCANTE; MUZZIO, 2008).

Sendo assim, Silva, Silva e Enders (apud COSTA; OLIVEIRA; CAVALCANTE; MUZZIO, 2008), apresenta um conceito de gestão ambiental que apresenta uma estrutura gerencial para avaliar e analisar os impactos das ações de uma organização no meio ambiente. Logo a organização deverá ter ferramentas para o entendimento e mensuração destes impactos ambientais.

Silva, Silva e Enders (apud COSTA; OLIVEIRA; CAVALCANTE; MUZZIO, 2008) destacam que:

fica evidente uma vinculação do conceito de gestão ambiental ao contexto organizacional, ou seja, a proposta relaciona-se mais ao impacto das ações organizacionais (principalmente empresariais), do que na composição de esforços para atingir a estes mesmos objetivos. A gestão ambiental seria, portanto, mais um conjunto de ações para minimizar o impacto das ações potencialmente agressivas ao meio ambiente, do que um conjunto de ações para contribuir para o alcance dos objetivos em si (SILVA, SILVA e ENDERS apud Costa; Oliveira; Cavalcante; Muzzio, 2008, p. 2).

A Câmara de Comércio Internacional -CCI (apud DONAIRE, 1999) entendendo a importância da proteção ambiental é uma das principais prioridades a ser buscado por qualquer tipo de negócio, destacou em seu documento, Business Charter For Sustainable Development, 16 princípios para a Gestão Ambiental.

\begin{tabular}{|l|l|l|l|}
\hline Princípios & Descrição & Princípios & Descrição \\
\hline $\begin{array}{l}\text { Prioridade } \\
\text { Organizacional }\end{array}$ & $\begin{array}{l}\text { Reconhecer a questão } \\
\text { ambiental como prioridade; } \\
\text { Estabelecer políticas, } \\
\text { programas e práticas. }\end{array}$ & Pesquisa & $\begin{array}{l}\text { Realizar ou apoiar } \\
\text { pesquisa que envolvam a a } \\
\text { variável ambiental. }\end{array}$ \\
\hline Gestão Integrada & $\begin{array}{l}\text { Integra a variável } \\
\text { ambiental em todas as } \\
\text { unidades de negócios; }\end{array}$ & $\begin{array}{l}\text { Enfoque } \\
\text { Preventivo }\end{array}$ & $\begin{array}{l}\text { Atuar em todas os níveis } \\
\text { organizacionais com enfoque a } \\
\text { prevenção do meio ambiente. }\end{array}$ \\
\hline $\begin{array}{l}\text { Processo } \\
\text { Melhoria }\end{array}$ & $\begin{array}{l}\text { Melhoras continuamente } \\
\text { as práticas, processos e } \\
\text { políticas ambientais da } \\
\text { empresa, bem suas }\end{array}$ & $\begin{array}{l}\text { Fornecedores e } \\
\text { Subcontratados }\end{array}$ & $\begin{array}{l}\text { Incentivar e contratar } \\
\text { fornecedores e empresas } \\
\text { subcontratados que tenham a } \\
\text { variável ambiental assimilada. }\end{array}$ \\
\hline
\end{tabular}




\begin{tabular}{|c|c|c|c|}
\hline & performances. & & \\
\hline Educação do Pessoal & $\begin{array}{l}\text { - Educar e treinar o } \\
\text { pessoal para que se } \\
\text { preocupem com a variável } \\
\text { ambiental em seu trabalho. }\end{array}$ & $\begin{array}{l}\text { Planos } \\
\text { Emergência }\end{array}$ & $\begin{array}{l}\text { - Em área de risco manter } \\
\text { planos de emergência que } \\
\text { atendam a todos os } \\
\text { stakeholders. }\end{array}$ \\
\hline $\begin{array}{l}\text { Prioridade } \\
\text { Enfoque }\end{array}$ & $\begin{array}{l}\text { - Realizar analises } \\
\text { ambientais antes das } \\
\text { tomadas de decisão. }\end{array}$ & $\begin{array}{l}\text { Transparência de } \\
\text { Tecnologia }\end{array}$ & $\begin{array}{l}\text { - Transferir e disseminar } \\
\text { tecnologia que sejam } \\
\text { amigáveis ao meio ambiente. }\end{array}$ \\
\hline Produtos e Serviços & $\begin{array}{l}\text { - Minimizar ou mitigar os } \\
\text { prejuízos } \\
\text { causados por produtos e } \\
\text { serviços. }\end{array}$ & $\begin{array}{l}\text { Contribuição ao } \\
\text { Esforço Comum }\end{array}$ & $\begin{array}{l}\text { - Contribuir e participar de } \\
\text { iniciativas publicas e privadas } \\
\text { que visem a proteção do meio } \\
\text { ambiente. }\end{array}$ \\
\hline $\begin{array}{l}\text { Orientação } \\
\text { Consumidor }\end{array}$ & $\begin{array}{l}\text { - Orientar os consumidores } \\
\text { para o transporte, uso e } \\
\text { descarte dos produtos. }\end{array}$ & $\begin{array}{l}\text { Transparência de } \\
\text { Atitude }\end{array}$ & $\begin{array}{l}\text { - Estabelecer diálogos com } \\
\text { todos os stakeholders sobre } \\
\text { possíveis risco decorrentes de } \\
\text { sua operação ao meio } \\
\text { ambiente. }\end{array}$ \\
\hline $\begin{array}{l}\text { Equipamentos e } \\
\text { Operacionalização }\end{array}$ & $\begin{array}{l}\text { - Utilizar de forma } \\
\text { eficiente os recursos naturais } \\
\text { exigidos pelos equipamentos } \\
\text { e operações; } \\
\text { - Minimizar os impactos } \\
\text { causados por eles ao meio } \\
\text { ambiente. }\end{array}$ & $\begin{array}{l}\text { Atendimento } \\
\text { Divulgação }\end{array}$ & $\begin{array}{l}\text { - Medir a performance } \\
\text { ambiental e avaliar } \\
\text { constantemente esta; } \\
\text { - Divulgar resultados a } \\
\text { todos os stakeholders. }\end{array}$ \\
\hline
\end{tabular}

Figura 2.4 - Princípios Para Gestão Ambiental

Fonte: Adaptado de CCI apud. Donaire (1999)

Fica evidente assim a importância da gestão ambiental para as organizações no novo contexto mundial. Bem como a importância do gestor da variável ambiental.

\subsubsection{Sistema de Gerenciamento Ambiental}

Para o INDG:

O Sistema de Gestão Ambiental permite que a organização atinja o nível de desempenho ambiental por ela determinado e promove sua melhoria contínua ao longo do tempo. Consiste, essencialmente, no planejamento de suas atividades, visando a eliminação ou minimização dos impactos ao meio ambiente, por meio de ações preventivas ou medidas mitigadoras (INDG).

Para a gestão da variável ambiental foram desenvolvidos alguns programas de gestão. Esses programas "estabelecem as atividades a serem desenvolvidas, a sequiência entre elas, bem como quem são os responsáveis pela sua execução.”(DONAIRE, 1999, p. 108). Alguns programas foram desenvolvidos, a saber: 
- Planos de ação e estratégia ecológica;

- Programa de atuação da ABIQUIM;

- Normas da série ISO 14000.

Alguns dos modelos foram adotados por empresas nos meados dos anos 90. Porém atualmente o sistema mais utilizado são as normas da série ISO 14000, pois além de ter uma série de normas e políticas ambientais, certifica as organizações com o chamado "selo verde". Isto faz com que as empresas se destaquem e consigam atrair os consumidores. O modelo proposta pela NBR ISO é exposto no modelo.

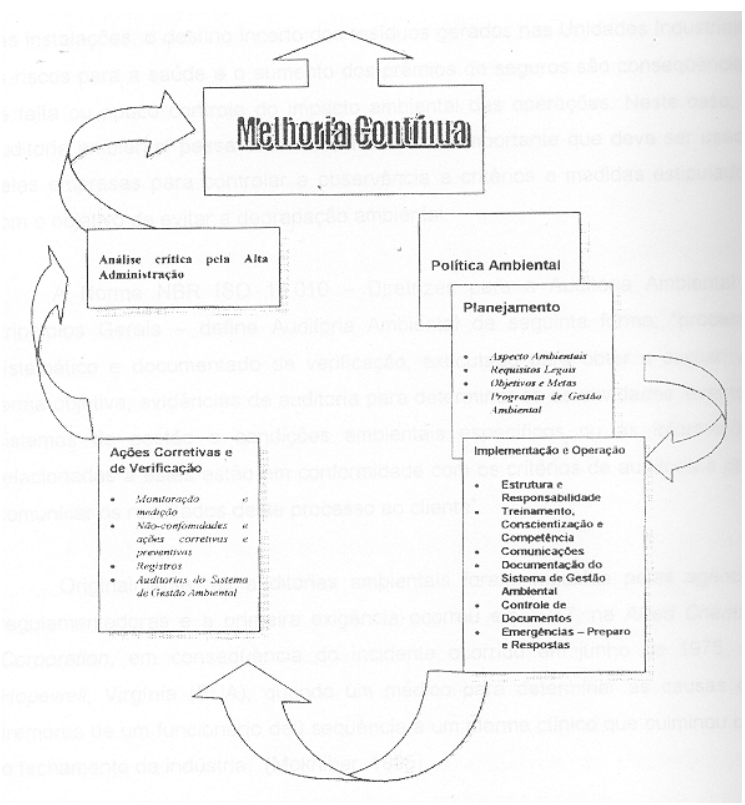

\section{Figura 2.5 - Modelo de Sistema de Gestão para Norma ISO 14001.}

Fonte: ABNT

A Norma ISO é baseada em uma série de princípios aplicáveis a qualquer empresa, quais sejam:

Princípio 1 - Comprometimento e Política;

Princípio 2 - Planejamento;

Princípio 3 - Implementação;

Princípio 4 - Medição e Avaliação; 


\section{Princípio 5 - Análise Crítica e Melhoria.}

Todavia o processo de normatização e aplicação da Norma ISO deve ser aplicada de forma a possibilitar a melhoria contínua dos processos e atividades de proteção do meio ambiente. Desta forma "tem por objetivo prover às organizações os elementos de um Sistema de Gestão Ambiental eficaz, passível de integração com os demais objetivos da organização. Sua concepção foi idealizada de forma a aplicar-se a todos e partes de organizações" (DONAIRE, 1999, p. 117).

\subsubsection{Benefícios da Gestão Ambiental}

A gestão ambiental aplicada de forma consciente e focada pode proporcionar segundo Dyllick (2000) uma série de benefícios para as organizações que aplicarem esta gestão. Estes benefícios irão depender do quão aplicada à gestão ambiental estará dentro da empresa. Os benefícios, potenciais, destacados por Dyllick (2000) são classificados com benefícios internos e externos.

\begin{tabular}{|l|l|}
\hline Benefícios Internos & Benefícios Externos \\
\hline Melhoria das medidas já existentes. & Melhora da imagem externa da empresa. \\
\hline Aumento da motivação dos colaboradores. & Possível vantagem competitiva. \\
\hline Prevenção de risco e problemas ambientais. & "Benefícios" em seguradoras e bancos \\
\hline Possível redução de custos. & $\begin{array}{l}\text { Possibilidades de maior rapidez com órgãos } \\
\text { ambientais }\end{array}$ \\
\hline
\end{tabular}

Figura 2.6 - Benefícios potenciais de um sistema de gestão ambiental.

Fonte: Dyllick et. al. (2000)

Além dos benefícios levantados por Dyllick (2000), North (1999) levanta mais 3 grupos de benefícios econômicos, possíveis, para empresas que implementam a gestão ambiental. $\mathrm{O}$ autor destaca que os benefícios para uma organização que faz o gerenciamento ambiental podem ser: Economia de custos; Aumento na receita e benefícios estratégicos. No 
mundo contemporâneo os benefícios de ter uma boa gestão ambiental vão além, muita vezes, fidelizam consumidores e destacam a organização em um cenário de alta concorrência.

\subsection{Estudos Relevantes a respeito de percepção da gestão ambiental no curso de administração}

Algumas pesquisas são relevantes para o estudo a ser realizado e demonstram a importância do tema gestão ambiental no curso de administração. A falta de um estudo nacional acerca do tema dificulta a verdadeira análise da situação real da perspectiva de importância para os futuros gestores brasileiros sobre o tema. Todavia existem estudos que caracterizam importantes vertentes sobre o assunto.

O estudo realizado por Costa (et. al., 2008) teve objetivo semelhante de analisar a percepção dos estudantes com relação à importância da Gestão Ambiental (em duas dimensões: formação e do conhecimento e da prática), além de analisar as intenções de envolvimento futuro dos estudantes em relação a essa área. A região estudada foi a do nordeste brasileiro. Foram entrevistados 190 estudantes de 25 instituições diferentes. O estudo concluiu que os estudantes atribuem grande importância para a gestão ambiental, em ambas as dimensões, porém apresentaram um baixo interesse de atuação futura na área.

Para Rigonat (apud. COSTA et. al., 2008).

Cabe às instituições de ensino protagonizarem o desenvolvimento de projetos de educação e de gestão ambiental, como um meio viável para uma formação profissional consistente e alinhada com as principais demandas atuais e futuras. Tal propósito requer uma forte concentração na identificação destas demandas, especialmente em nível local. Ademais, além da formação da consciência, requer-se, também, a formação de competências para atuação em um contexto complexo e multidisciplinar (RIGONAT apud Costa et. al., 2008, p. 1).

Outro estudo que caracteriza a gestão ambiental nas Instituições de Ensino Superior é o realizado por Ferreira e Ferreira (2008) que tinha como objetivo, verificar o grau de inserção da disciplina de gestão ambiental na matriz curricular dos cursos de graduação em Administração de Empresas oferecidos pelas IES (Instituições de Ensino Superior) do estado de Santa Catarina. O estudo demonstrou que a disciplina é oferecida em um número considerável de instituições no estado de Santa Catarina e deve ser considerada importante na 
formação dos acadêmicos. Porém o estudo aponta que a maior dificuldade enfrentada para incluir a disciplina nos cursos superiores é a adaptação da matriz curricular.

Estudos como o de Barbieri (2004) que evidencia a problemática da implementação da educação ambiental (EA) em cursos de graduação em administração, conforme estabelece a legislação brasileira, destaca a importância deste tema na formação do futuros administradores brasileiro e a dificuldade da implementação desta disciplina. (FERREIRA e FERREIRA, 2008; DIAS, 2009). Soma-se a estes a pesquisa de Costa e Oliveira (2008) que busca avaliar a importância atribuída por professores de Instituições de Ensino Superior em Administração para a área de Gestão ambiental. E os resultados são:

(1) os professores avaliam que a gestão ambiental é uma área de grande relevância para os cursos de Administração, e ainda que haja uma necessidade moderada desta área nos cursos; (2) por outro lado, e apesar da grande relevância atribuída, o nível de intenções de envolvimento dos professores com a área foi baixo (COSTA e OLIVEIRA, 2008, p. 1).

Os estudos buscaram apresentar diferentes visões dos agentes participantes do processo de construção de uma unidade sobre o tema da gestão ambiental e os administradores. O tema é novo e está em plena construção não existe uma opinião formada acerca do inclusão ou não de uma matéria no curso, apenas indícios de que a falta dela traz um enorme prejuízo na formação acadêmica dos administradores. 


\section{MÉTODOS E TÉCNICAS DE PESQUISA}

\subsection{Delineamento da pesquisa}

A metodologia utilizada para a segunda etapa é do tipo quantitativo descritiva. A pesquisa descritiva é caracterizada por ter o "objetivo primordial a descrição das características de determinada população ou fenômeno ou, então, o estabelecimento de relações entre variáveis. [...] e a utilização de técnicas padronizadas de coleta de dados, tais como questionário e a observação sistemática"(GIL, 2002, p.42).

As variáveis apresentadas para ser estudadas são consideradas de natureza quantitativa e os dados serão óbitos por de meio de aplicação de questionários com perguntas fechadas, de escala numérica e de múltipla escolha.

\subsection{Descrição das variáveis de pesquisa}

As variáveis pesquisadas foram dividas em três macro temas quais sejam: Importância do conhecimento em gestão ambiental, Papel dos cursos de Administração em relação a gestão ambiental, Intenções futuras em relação a gestão ambiental.

O primeiro trata da importância do conhecimento em gestão ambiental para os pesquisados.

O segundo diz respeito a importância do curso de administração para a formação em gestão ambiental.

O terceiro visa analisar as intenções futuras dos pesquisados quanto a atuação com gestão ambiental.

Além dos três macro temas analisados julgou-se relevante analisar um fator criado por Costa; Oliveira; Cavalcante; Muzzio (2008) para determinar a importância para os alunos da prática em gestão ambiental. Para tanto foi criado um fator com um mix dos itens dos macro temas apresentados.

\subsection{População e amostra}

Para a população do estudo considerou-se todos os estudantes do curso de administração de empresas (diurno e noturno) da Universidade de Brasília do Campus Darcy 
Ribeiro no Plano Piloto; ensino presencial que somam aproximadamente 1000 alunos. Para a pesquisa foi definida uma amostra não probabilística e intencional (escolhida por conveniência), composta de alunos formandos no período letivo de 2009/1.

Segundo o departamento de Administração da Universidade de Brasília o total de possíveis formando nos cursos de administração de empresas diurno e noturno são de 106 alunos. Como o estudo objetiva pesquisar a perspectiva da importância para alunos de administração, percebe-se importante que a amostra seja caracterizada por alunos em estágio avançado ou termino do curso, para que estes tenham tido a possibilidade do contato prévio com o assunto ou mesmo pesquisado por conta própria. Além de que os alunos em estágio avançado normalmente possuem experiência profissional, o que caracteriza maior conhecimento tácito de administração, possibilitando assim o maior conhecimento dos construtos a serem pesquisados.

A amostra final analisada foi alterada devido a motivo de força maior como a desistência de alunos no decorrer da disciplina Estágio Supervisionado.

\subsection{Procedimentos e instrumentos utilizados na coleta e análise dos dados}

O questionário utilizado na pesquisa foi dividido em três seções. A primeira refere-se a experiência profissional dos público alvo. A segunda trata especificamente do construto alvo desta pesquisa a gestão ambiental. A terceira seção é dedicada ao interesse dos dentro das sub-áreas da administração e questões socioeconômicas.

O instrumento utilizado para a realização da pesquisa foi um questionário utilizado na pesquisa de Costa et. al. (2008).

Para a definição dos itens dos construtos, e visando a análise da relevância da gestão ambiental, foi especialmente importante o estudo de Sleeper et al. (2006), no qual foi desenvolvida uma escala para avaliação do 'papel da educação em negócios em relação aos temas sociais' (Escala BERSI - [B]usiness [E]ducation's [R]ole in addressing [S]ocial [I]ssues). Os 10 itens desta escala foram traduzidos, analisados e adaptados para o contexto da gestão ambiental (substituindo os temas sociais). Além dos itens da escala, também foram definidos, a partir dos tópicos da literatura pesquisada, quatro itens para avaliar a predisposição dos estudantes em manter envolvimento futuro com a gestão ambiental (COSTA et. al., 2008, p.6). 
Os itens que descrevem a percepção da relevância da gestão ambiental foram colocados como afirmações, "com averiguação do grau de concordância por meio de uma escala Likert de 5 pontos, com extremos de 1 para 'discordância total', e 5 para a 'concordância total' “(COSTA et. al., 2008, p.6).

"Já nos quatro itens sobre intenções futuras, questionava-se a probabilidade do respondente seguir a alternativa de envolvimento proposta, em uma escala de 5 pontos, com extremos de 1 para ‘muito improvável', e 5 para ‘muito provável” (COSTA et. al., 2008, p.6).

Algumas questões foram retiradas do questionário devido ao público das pesquisas serem diferentes, a retirada destas questões não acarretou problemas de interpretação do questionário. Para a melhor análise da pesquisa foram incluídas algumas questões (questões 1,2,3,10 e 11) o que também não afetou a interpretação do questionário.

Os questionários foram aplicados no período de 20 de maio de 2009 ao dia 03 de junho de 2009, no horário da disciplina Estágio Supervisionado, realiza por alunos concluintes do curso público alvo desta pesquisa, por concentrar os respondentes a aplicação dos questionários foi facilita, uma vez que a maioria dos alunos formandos compareceu as aulas da disciplina. Os alunos que não haviam respondido o questionário foram abordados em horário de outras disciplinas.

A tabulação e análise dos dados foram realizadas em software Microsoft Office Excel 2007.

\subsection{Comentários sobre o processo da coleta de dados}

Os questionários válidos foram primeiramente numerados e posteriormente tabulados em planilhas do software Microsoft Office Excel 2007, planilhas estas diagramadas pelo próprio autor desta pesquisa. Utilizaram-se fórmulas estatísticas e numéricas pré-existente no software para melhor análise e interpretação dos dados tabulados.

As análises estatísticas e interpretativas foram realizadas pergunta a pergunta, bem como a partir de cruzamento de perguntas que o autor julgou necessário para o melhor aproveitamento dos dados obtidos com a pesquisa. 


\section{APRESENTAÇÃO E ANÁLISE DOS RESULTADOS DA PESQUISA}

Os resultados obtidos na pesquisa são apresentados em forma de tabelas para facilitar o entendimento. As análises realizadas a partir dos resultados da pesquisa serão descritos no decorrer deste capítulo.

A apresentação dos dados será feita por meio de médias, desvio-padrão, moda e frequências absoluta e relativa demonstrando claramente o conjunto de opiniões e constatações dos resultados da pesquisa.

Foram aplicados 85 questionários. O número de questionários válidos para a pesquisa foi de 78. Esta redução deveu-se a questionários inválidos com marcações incorretas ou com duplicidade na marcação, bem como questionários sem respostas ou parcialmente respondidos. A partir do total válido de questionário a análise foi realizada.

\subsection{Dados demográficos dos respondentes}

Primeiramente é necessário realizar uma caracterização dos respondentes deste estudo, para tanto algumas informações são importantes.

Tabela 1. - Caracterização dos respondentes entrevistados

\begin{tabular}{l|l|c|c}
\hline \multicolumn{1}{c|}{ Variávels } & \multicolumn{1}{|c|}{ Descrição das Categorias } & $\begin{array}{c}\text { Frequência } \\
\text { Absoluta }\end{array}$ & $\begin{array}{c}\text { Frequência } \\
\text { Relativa }\end{array}$ \\
\hline Sexo & Masculino & 43 & $55 \%$ \\
& Feminino & 35 & $45 \%$ \\
\hline Idade & Até 21 anos & 7 & $9 \%$ \\
& Acima de 21 até 24 anos & 59 & $76 \%$ \\
& Acima de 24 & 12 & $15 \%$ \\
\hline Períodos letivos no crusos & Até 7 semestres & 6 & $8 \%$ \\
& Entre 8 e 10 semestres & 62 & $79 \%$ \\
& Acima de 11 semestres & 10 & $13 \%$ \\
\hline Estado civil & Solteiro/vive só & 71 & $91 \%$ \\
& Casado/vive com alguém & 7 & $9 \%$ \\
\hline Renda familiar & Até $R \$ 1000,00$ & 0 & $0 \%$ \\
& Acima de $R \$ 1000,00$ até $\mathrm{R} \$ 2000,00$ & 12 & $15 \%$ \\
& Acima de $\mathrm{R} \$ 2000,00$ até $\mathrm{R} \$ 3000,00$ & 5 & $6 \%$ \\
& Acima de $\mathrm{R} \$ 3000,00$ até $\mathrm{R} \$ 4000,00$ & 4 & $5 \%$ \\
& Acima de $\mathrm{R} \$ 4000,00$ & 57 & $73 \%$ \\
\hline
\end{tabular}

Fonte: Dados da pesquisa. 
Quanto ao gênero dos respondentes a maioria é do sexo masculino com 55\% das respostas. Dado que diverge da pesquisa de Costa et. al (2008), com 46,6\% de alunos do sexo masculino. O resultado da pesquisa demonstra algo semelhante ao que aponta a Secretária de Planejamento da UnB que indica que dos alunos formandos em 2/2008 39,5\% foi de mulher.

Quando à idade dos pesquisados, na faixa de 21 a 24 anos há $76 \%$ das respostas. Os respondentes que tem 24 anos ou mais somam 15\% e apenas $9 \%$ estão finalizando o curso de administração com até 21 anos de idade.

Os resultados da pesquisa indicam que mais de $79 \%$ dos pesquisados estão concluindo o curso de Administração de Empresa diurno e noturno entre 8 e 10 períodos letivos. Com uma média de 9,25 períodos letivos. Este resultado reflete que o tempo estimado pelo matriz curricular do curso está coerente, pois atualmente o curso tem duração curricular de 9 períodos letivos o que demonstra que os respondentes estão dentro da faixa esperada pelo departamento de administração. $\mathrm{O}$ total de respondentes que estão graduando com até 7 períodos letivos cursados é de $8 \%$ e os que estão concluindo com mais de 11 semestres somam $13 \%$.

Para a variável estado civil cerca de $91 \%$ dos respondentes são solteiros ou vivem só, e 9\% são casados ou vivem com alguém.

A renda familiar dos participantes desta pesquisa é diferente da pesquisa de Costa et. al. (2008) realizada com público semelhante ao deste estudo. Em sua pesquisa o autor encontrou concentrações bem divididas entre as faixas de renda familiar e apenas $21,4 \%$ dos pesquisados possuíam renda familiar acima de $\mathrm{R} \$ 4000,00$. No presente estudo a concentração de respondentes mesma faixa de renda familiar é de $73 \%$. Esta diferença pode ser explicada pelo fato das pesquisas terem sido realizadas em regiões distintas do país. A primeira na região nordeste e a segunda em Brasília, Centro Oeste, onde a população possui a maior renda familiar do país com R \$3.241,00 segundo o IBGE.

\subsection{Experiência profissional e área de interesse dos respondentes}

Percebeu-se importante identificar se os respondentes estavam estagiando/trabalhando ou se já haviam estagiado/trabalhado. Pois o contato com o ambiente não acadêmico é importante para a formação do estudante de administração e também proporciona contato com diversas realidades, inclusive com a dos construtos pesquisados 
neste estudo. Os resultados mostraram que $98,7 \%$ dos formandos estagiam/trabalham ou já estagiaram/trabalharam. Apenas um respondente não o fez. Essa informação demonstra que os respondentes têm ou tiveram um contato com o mercado o que proporciona uma visão mais ampla dos conhecimentos aprendidos na academia.

Tabela 2. - Experiência profissional.

\begin{tabular}{l|c|c|c}
\hline \multicolumn{1}{c|}{ Variável } & $\begin{array}{c}\text { Descrição das } \\
\text { Categorias }\end{array}$ & $\begin{array}{c}\text { Frequência } \\
\text { Absoluta }\end{array}$ & $\begin{array}{c}\text { Frequência } \\
\text { Relativa }\end{array}$ \\
\hline Trabalha/estagia ou já & $\operatorname{sim}$ & 77 & $98,7 \%$ \\
trabalhou/estgiou & não & 1 & $1,3 \%$ \\
\hline
\end{tabular}

Fonte: Dados da pesquisa.

Porém os resultados se alteram quando a variável é a inserção atual no mercado de trabalho. Os respondentes que afirmam estar trabalhando/estagiando atualmente é de $79 \%$ e os que estão fora do mercado de trabalho é de $21 \%$. Este dado pode ser explicado pelo fato da pesquisa ter sido realizada em Brasília onde a concentração de órgãos e organizações do poder público é alto o que leva aos recém formados a optarem muitas vezes por estudar para ingressar no setor público.

Tabela 3. - Inserção no mercado de trabalho

\begin{tabular}{c|c|c|c}
\hline Variável & Descrição das Categorias & $\begin{array}{c}\text { Frequência } \\
\text { Absoluta }\end{array}$ & $\begin{array}{c}\text { Frequência } \\
\text { Relativa }\end{array}$ \\
\hline Trabalha/estagia atualmente & $\operatorname{sim}$ & 62 & $79 \%$ \\
& não & 16 & $21 \%$ \\
\hline
\end{tabular}

Fonte: Dados da Pesquisa

A fim de caracterizar o público alvo da presente pesquisa perguntou-se qual a área de interesse dentro da administração que mais atraia o respondente. A divisão das "sub-áreas" da administração foi adaptada da divisão das linhas de pesquisa existentes na ANPAD. 
Tabela 4. - Distribuição dos respondentes quanto as áreas de interesse na administração.

\begin{tabular}{l|l|c|c}
\hline Variável & \multicolumn{1}{|c|}{ Descrição das Categorias } & $\begin{array}{c}\text { Frequência } \\
\text { Absoluta }\end{array}$ & $\begin{array}{c}\text { Frequência } \\
\text { Relativa }\end{array}$ \\
\hline Área de interesse & Finanças & 16 & $21 \%$ \\
& Marketing & 20 & $26 \%$ \\
& Gestão de pessoas e relações de trabalho & 13 & $17 \%$ \\
& Gestão de operações e logística & 4 & $5 \%$ \\
& Estratégia em organizações & 12 & $15 \%$ \\
& Gestão de tecnologia e informação & 0 & $0 \%$ \\
& Administração pública / Gestão Social & 13 & $17 \%$ \\
& Administração da Informação & 0 & $0 \%$ \\
\hline
\end{tabular}

Fonte: Dados da pesquisa.

As áreas que mais despertam o interesse dos pesquisados foram as área de Marketing e Finanças com a concentração $26 \%$ e $21 \%$ respectivamente. Estas áreas são bastante tradicionais na administração, já áreas relativamente novas que tratam de tecnologia e conhecimento, tiveram $0 \%$ de respostas tais como Gestão de Tecnologia e Informação e Administração da Informação.

Outro dado relevante é a escolha da área de Administração pública/Gestão Social por $17 \%$ dos pesquisado. As outras áreas obtiveram um percentual de respostas menor ou igual ao desta ultima, gestão de pessoas (17\%), estratégia em organizações (15\%) e gestão e logística $(5 \%)$.

Atualmente o curso de administração (diurno e noturno) não disponibiliza uma disciplina obrigatória ou optativa que trate especificamente de gestão ambiental. Foi perguntado então aos alunos se haviam cursado alguma disciplina que abordasse o tema.

Tabela 5. - Distribuição dos respondentes quanto a ter cursado disciplina com o tema gestão ambiental.

\begin{tabular}{l|c|c|c}
\hline \multicolumn{1}{c|}{ Variável } & Descrição das Categorias & $\begin{array}{c}\text { Frequência } \\
\text { Absoluta }\end{array}$ & $\begin{array}{c}\text { Frequência } \\
\text { Relativa }\end{array}$ \\
\hline $\begin{array}{l}\text { Cursou alguma disciplina } \\
\text { que abordou o tema } \\
\text { gestão ambiental }\end{array}$ & sim & 19 & $24,4 \%$ \\
\hline
\end{tabular}

Fonte: Dados da pesquisa.

Os resultados demonstraram que $24 \%$ dos respondentes já participaram de alguma disciplina que abordou o tema gestão ambiental. Isto pode demonstrar um interesse dos alunos 
em se capacitar em tal tema, visto que alguns procuraram disciplinas fora do currículo para complementar o conhecimento.

Julgou-se interessante analisar uma possível relação entre os pesquisados que cursaram alguma disciplina que abordou o tema gestão ambiental e o macro tema Intenções futuras em relação a gestão ambiental. Analisou-se que 47\% ( 9 questionários) tiveram a moda de 3 na escala Likert deste fator. Demonstrando assim que neste estudo os alunos que tiveram contato com o uma disciplina de gestão ambiental assinalaram 3 ou mais nos itens do fator de intenções futuras com relação a gestão ambiental.

Para a introdução ao tema da pesquisa e iniciação dos questionamentos acerca dos construtos, viu-se necessário identificar os respondentes que tiveram contato com gestão ambiental.

Tabela 6. - Distribuição dos respondentes quanto a ter realizado alguma atividade associada à gestão ambiental.

\begin{tabular}{l|c|c|c}
\hline \multicolumn{1}{c|}{ Variável } & Descrição das Categorias & $\begin{array}{c}\text { Frequência } \\
\text { Absoluta }\end{array}$ & $\begin{array}{c}\text { Frequência } \\
\text { Relativa }\end{array}$ \\
\hline $\begin{array}{l}\text { Realizou alguma atividade } \\
\text { associada a gestão } \\
\text { ambiental }\end{array}$ & sim & 15 & $19 \%$ \\
\hline
\end{tabular}

Fonte: Dados da pesquisa.

Para o envolvimento com atividades associadas a gestão ambiental o resultado da pesquisa demonstra que $81 \%$ dos entrevistados não realizou nenhuma atividade que envolvesse o tema de gestão ambiental. O que é preocupante já que o tema em questão está em constante ascensão e é cada vez mais cobrado dento de grandes organizações como uma variável muito importante para o crescimento da empresa, como destaca Donaire (2004).

Para os respondentes que tinham se envolvido com alguma atividade em gestão ambiental, foi perguntado qual a natureza deste envolvimento. Dos $19 \%$ respondentes que já realizaram alguma atividade que envolvesse gestão ambiental 33\% responderam que trabalham diretamente com o tema. A pesquisa mostrou ainda que $27 \%$ dos respondentes que tiveram envolvimento com atividade em gestão ambiental realizam atividades junto a Organizações não Governamentais (ONG’s).

Tabela 7. - Distribuição das atividades realizadas associadas a gestão ambiental. 


\begin{tabular}{c|l|c|c}
\hline \multicolumn{1}{c|}{ Variável } & \multicolumn{1}{|c}{ Descrição das Categorias } & $\begin{array}{c}\text { Frequência } \\
\text { Absoluta }\end{array}$ & $\begin{array}{c}\text { Frequência } \\
\text { Relativa }\end{array}$ \\
\hline Qual a atividade realizada & Meu trabalho envolve gestão ambiental & 5 & $33 \%$ \\
& Projeto na faculdade & 4 & $27 \%$ \\
& Trabalhos para empresas especializadas em gestão ambiental & 0 & $0 \%$ \\
& Atividades juntos a Organizações Não Governamentais (ONGs) da área & 4 & $27 \%$ \\
& Outros & 2 & $13 \%$ \\
\hline
\end{tabular}

Fonte: Dados da pesquisa.

Os formandos que responderam a ultima opção, "outros", descreveram atividades pessoais de gestão ambiental, como projeto de coleta seletiva de lixo e projeto no parque local de conscientização de usuários.

\subsection{Percepção dos respondentes quanto à gestão ambiental}

As questões 6, 7, 8 e 9 referem-se diretamente ao construto de gestão ambiental.

O atual curso de Administração de Empresas da Universidade de Brasília não oferece uma disciplina voltada especificamente para gestão ambiental ou algo similar como mencionado anteriormente. Todavia está em andamento a reforma da matriz curricular do curso de administração e que possivelmente contemplará uma disciplina para abordar este conhecimento. Foi perguntado aos formandos como a gestão ambiental deveria ser abordada.

Tabela 8. - Percepção dos respondentes de como a gestão ambiental deve ser tratada na Academia.

\begin{tabular}{c|l|c|c}
\hline \multicolumn{1}{c|}{ Variável } & \multicolumn{1}{|c}{ Descrição das Categorias } & $\begin{array}{c}\text { Frequência } \\
\text { Absoluta }\end{array}$ & $\begin{array}{c}\text { Frequência } \\
\text { Relativa }\end{array}$ \\
\hline Gestão ambiental deveria ser: & Tratado somente em nível de pós-graduação & 4 & $5 \%$ \\
& Uma disciplina dos currículos de graduação em Administração & 36 & $46 \%$ \\
& Um curso independente & 1 & $1 \%$ \\
& Analisado com conteúdo interdisciplinar de cursos de Administração & 26 & $33 \%$ \\
& Tratado como Atividade Complementar & 7 & $9 \%$ \\
& Outros & 4 & $5 \%$ \\
\hline
\end{tabular}

Fonte: Dados da pesquisa.

A pesquisa revela que $46 \%$ dos participantes da pesquisa apontam que a gestão ambiental deve estar presente como uma disciplina obrigatória na matriz curricular do curso de administração. Isto demonstra uma preocupação dos estudantes com a formação em gestão ambiental no curso de administração. Refletindo muito bem a pesquisa de Ferreira; Ferreira (2008) que aferiu em seu estudo que a disciplina gestão ambiental no curso de administração, das instituições de ensino superior de Santa Catarina, deve ser considerada importante para a formação dos acadêmicos. Corrobora ainda a idéia de Barbieri (2004) que reforça a disciplina gestão ambiental como importante fator para a formação dos alunos de administração. 
Outro dado interessante da pesquisa é que $34,5 \%$ dos entrevistados avaliam que a gestão ambiental deve ser tratada de forma interdisciplinar no curso de administração mostrando um entendimento semelhante ao de Almeida (2007) que avalia a variável ambiental nas organizações como interdisciplinar e multifacetada, o que exige dos gestores visões mais ampla da organização. Enquadrando-se também na concepção de Rigonat (apud Costa et. al. 2008) que diz que a formação dos administradores em gestão ambiental deve ser não de consciência, mas também de competências para atuação em um contexto complexo e multidisciplinar. Além de muito outros estudos que possuem o mesmo resultado (BARBIERI, 2004; DIAS et. al., 2009; FERREIRA; FERREIRA, 2008).

Para as questões 7,8 e 9 foi utilizado uma escala Likert de 1 a 5 como mencionado anteriormente. A análise de dados foi realizada para cada um dos itens avaliados dentro dos macro temas especificados no questionário.

O primeiro macro tema analisado foi a Importância do conhecimento de gestão ambiental. A avaliação foi realizada mediante 5 itens sobre este macro tema.

Tabela 9. - Média, moda e desvio padrão da percepção de importância do conhecimento em gestão ambiental.

\begin{tabular}{l|r|r|r}
\hline \multicolumn{1}{c|}{ Variáveis } & \multicolumn{1}{c|}{ Média } & Desv. Padrão & \multicolumn{1}{c}{ Moda } \\
\hline $\begin{array}{l}\text { O aprendizado sobre gestão ambiental é um assunto de grande } \\
\text { importância para a formação em Administração }\end{array}$ & 3,97 & 1,05 & 5,00 \\
\hline $\begin{array}{l}\text { Uma boa formação em Administração passa pela formação em } \\
\text { gestão ambiental }\end{array}$ & 3,40 & 1,12 & 3,00 \\
\hline $\begin{array}{l}\text { Graduandos em Administração devem saber como resolver } \\
\text { problemas de gestão ambiental }\end{array}$ & 3,63 & 1,08 & 4,00 \\
\hline $\begin{array}{l}\text { Escolas de Administração deveriam oferecer oportunidades para } \\
\text { que os estudantes aumentem sua compreensão sobre gestão } \\
\text { ambiental }\end{array}$ & 4,34 & 0,84 & 5,00 \\
\hline $\begin{array}{l}\text { Escolas de Administração deveriam incentivar estudantes para se } \\
\text { envolverem em projetos ambientais }\end{array}$ & 4,19 & 0,87 & 5,00 \\
\hline Média do Fator & $\mathbf{3 , 9 1}$ & & $\mathbf{0 , 9 9}$ \\
\hline Desvio Padrão do fator & & \multicolumn{2}{|c}{} \\
\hline
\end{tabular}

Fonte: Dados da pesquisa.

A importância do tema gestão ambiental ficou evidenciada ao longo do presente estudo tanto pelo contexto que o planeta se encontra (pressão sobre matérias primas, aquecimento global, desmatamento entre outros) como também pelas novas necessidades e o novo ambiental mercadológico global. O aprendizado sobre gestão ambiental torna-se importante para a formação dos futuros administrados é o que aponta a pesquisa realizada 
onde a média de repostas para as variáveis utilizadas para aferição ficou em 3,90 e um desvio padrão de 0,99 , consideram o aprendizado sobre gestão ambiental como sendo de grande importância para a formação em administração. Já que a escala Likert de análise compreendia um intervalo entre 1 a 5.

Este dado corrobora a pesquisa de Costa; Oliveira; Cavalcante; Muzzio (2008) onde a média desta variável ficou em 4,45. Esta diferença pode ser devido a pesquisa dos autores ter sido realizada em uma amostra maior e em um ambiente acadêmico onde já havia a disciplina relacionada à gestão ambiental. Estudos como o de Donaire (2004) evidenciam a variável ambiental com uma variável muito complexa e extremamente importante para as organizações.

Krieger et. al. (2006) salienta que as organizações devem buscar abordar os problemas ambientais causados pelo fruto de sua existência. Já Maimon (1996), aponta a gestão ambiental como uma vantagem competitiva o que torna esta variável ambiental estratégica dentro das organizações, assim como os responsáveis por sua gestão.

\section{O Segundo macro tema foi o Papel dos cursos de Administração em relação a} gestão ambiental. A avaliação também foi realizada mediante 5 itens sobre este macro tema.

Tabela 10. - Média, moda e desvio padrão da percepção de importância do papel do curso de administração em relação a gestão ambiental.

\begin{tabular}{l|r|r|r}
\hline \multicolumn{1}{c|}{ Variáveis } & Média & Desv. Padrão & Moda \\
\hline $\begin{array}{l}\text { Cursos de Administração deveriam envolver os estudantes em } \\
\text { assuntos ambientais }\end{array}$ & 3,91 & 0,91 & 4,00 \\
\hline $\begin{array}{l}\text { Cursos de Administração deveriam preparar estudantes para ser } \\
\text { líderes de projetos ambientais }\end{array}$ & 3,28 & 1,06 & 3,00 e 4,00 \\
\hline $\begin{array}{l}\text { Cursos de Administração deveriam avaliar nos alunos } \\
\text { conhecimentos sobre responsabilidade ambiental }\end{array}$ & 3,38 & 1,02 & 4,00 \\
\hline $\begin{array}{l}\text { Cursos de Administração deveriam incluir no currículo } \\
\text { conteúdos/disciplinas sobre gestão ambiental }\end{array}$ & 4,12 & 0,95 & 5,00 \\
\hline $\begin{array}{l}\text { Cursos de Administração deveriam incluir tópicos nas várias } \\
\text { disciplinas sobre responsabilidade ambiental }\end{array}$ & 3,85 & 0,90 & 4,00 \\
\hline Média do Fator & $\mathbf{3 , 7 1}$ & & \multicolumn{2}{|c|}{$\mathbf{0 , 9 7}$} \\
\hline Desvio Padrão do fator & &
\end{tabular}

Fonte: Dados da pesquisa.

Para o presente estudo a análise do macro tema "papel do curso de administração em relação à gestão ambiental" é relevante visto que não existe uma disciplina para orientar os alunos quanto ao tema na universidade onde os respondentes se localizam. 
A avaliação dos pesquisados quanto a este macro tema foi mais baixa do que a análise anterior tendo uma média de 3,70 e uma dispersão de 0,97. Mesmo sendo mais baixa comparativamente com a anterior, o dado é interessante uma vez que os alunos atribuem uma importância relevante mesmo sem ter tido a experiência acadêmica de formação em gestão ambiental no curso de administração que estão concluindo.

O que corrobora o estudo como o de Costa; Oliveira (2008) que mostra a opinião dos professores de administração sobre a área de gestão ambiental. Um dos resultados da pesquisa foi que "os professores avaliam que a gestão ambiental é uma área de grande relevância para os cursos de Administração" (COSTA; OLIVEIRA, 2008).

Tal resultado salienta também a importância do Departamento de Administração da Universidade criar uma disciplina que proporcione aos alunos de administração o contato com as teorias e práticas da gestão ambiental.

Um dos objetivos deste estudo é diagnosticar a importância para os alunos da prática em gestão ambiental. Para a análise deste objetivo, utilizou-se o mesmo fator da análise realizado por Costa; Oliveira; Cavalcante; Muzzio (2008), julgando-se adequado a divisão fatorial realizada pelos autores, que consideraram os itens a seguir como definidores da opinião dos alunos sobre a importância da prática em gestão ambiental.

Tabela 11.- Média, moda e desvio padrão da percepção de importância da prática de gestão ambiental.

\begin{tabular}{l|r|r}
\hline \multicolumn{1}{c|}{ Variáve is } & \multicolumn{1}{c|}{ Média } & Desv. Padrão \\
\hline $\begin{array}{l}\text { Cursos de Administração deveriam envolver os estudantes em } \\
\text { assuntos ambientais }\end{array}$ & 3,91 & 0,91 \\
\hline $\begin{array}{l}\text { O aprendizado sobre gestão ambiental é um assunto de grande } \\
\text { importância para a formação em Administração }\end{array}$ & 3,97 & 1,05 \\
\hline $\begin{array}{l}\text { Escolas de Administração deveriam oferecer oportunidades para } \\
\text { que os estudantes aumentem sua compreensão sobre gestão } \\
\text { ambiental }\end{array}$ & 4,34 & 0,84 \\
\hline $\begin{array}{l}\text { Escolas de Administração deveriam incentivar estudantes para se } \\
\text { envolverem em projetos ambientais }\end{array}$ & 4,19 & 0,87 \\
\hline $\begin{array}{l}\text { Graduandos em Administração devem saber como resolver } \\
\text { problemas de gestão ambiental }\end{array}$ & 3,63 & 1,08 \\
\hline Média do Fator & $\mathbf{4 , 0 1}$ & \\
\hline Desvio Padrão do fator & & $\mathbf{0 , 9 5}$ \\
\hline
\end{tabular}

Fonte: Dados da pesquisa. 
Constatou-se que os alunos consideram importante o conhecimento prático em gestão ambiental uma vez que a média das respostas a variáveis de analise foi de 4,00 e o desvio padrão de 0,95 . Sendo mais baixas também que a pesquisa dos autores que elaboraram a analise fatorial, em sua pesquisa a média foi bastante elevada $(4,59)$ e o desvio padrão mostrou uma coerência muito grande entre os respondentes $(0,49)$.

A exposição a situações práticas de problemas ambientais ajuda a criar uma consciência ecológica maior, maximizando assim o seu aprendizado em cursos de administração com salienta o estudo de Dias et. al., (2009). O conhecimento prático de gestão ambiental é essencial para a formação do "gestor ambiental" para o aprimoramento e desenvolvimento de práticas eficientes, criando assim benefícios econômicos como, economia de custos; aumento na receita e benefícios estratégicos (NORTH, 1999).

\section{O Terceiro macro tema foi as Intenções futuras em relação a gestão ambiental,} por parte dos formandos. A avaliação foi realizada mediante 4 itens, conforme Tabela $12 .$.

Tabela 12. - Média, moda e desvio padrão da intenção futura de envolvimento com gestão ambiental.

\begin{tabular}{l|r|r|r}
\hline \multicolumn{1}{c|}{ Variáveis } & \multicolumn{1}{c|}{ Média } & Desv. Padrão & \multicolumn{1}{c}{ Moda } \\
\hline Probabilidade de fazer cursos diversos na área de gestão ambiental & 2,69 & 1,00 & 3,00 \\
\hline Probabilidade de me envolver em projetos ambientais & 3,12 & 1,07 & 3,00 \\
\hline Probabilidade de fazer uma pós-graduação em gestão ambiental & 2,09 & 0,97 & 3,00 \\
\hline Probabilidade de trabalhar como gestor ambiental & 2,26 & 0,96 & 3,00 \\
\hline Média do Fator & $\mathbf{2 , 5 4}$ & & \multicolumn{2}{|c|}{$\mathbf{0 , 9 9 8}$} \\
\hline Desvio Padrão do fator & & \multicolumn{2}{|c}{} \\
\hline
\end{tabular}

Fonte:Dados da pesquisa.

Os resultados da pesquisa mostram que o cenário muda em relação às intenções futuras de atuação dos formandos na área o cenário de avaliação dos pesquisados foi diferente.

Com uma média de 2,54, muito inferior as demais análises e uma dispersão de 0,99. Não sendo atribuída a essa baixa média o fato de não existir estímulos acadêmicos sobre o tema, pois na pesquisa realizado por Costa; Oliveira; Cavalcante; Muzzio (2008) percebeu-se o mesmo comportamento estatístico das repostas. Essa falte de interesse pode estar associada a falta de conhecimento sobre carreiras na setor de gestão ambiental ou ao fato do público 
pesquisa na presente pesquisa estar na cidade de Brasília onde a oferta de emprego público e sensivelmente maior do que no restante do país. Atraindo assim muitos administradores a atuar no setor público.

\section{CONCLUSÕES}

O objetivo geral do presente estudo foi analisar a importância atribuída pelos alunos de graduação em administração da Universidade de Brasília (UnB) acerca da gestão ambiental. Para se chegar a este objetivo foi definida uma amostra para pesquisa. Entendeu-se que os alunos em final de curso (formandos) seria a melhor escolha uma vez que a universidade onde a publico alvo esta inserido não oferecia nenhuma matéria que a abordasse o construto central da pesquisa.

Os resultados da pesquisa apontam, de uma forma ampla que os futuros administradores formados pela Universidade compreendem a importância que a gestão ambiental tem dentro e fora da universidade. Mesmo o curso não disponibilizando uma disciplina voltada exclusivamente para o tratamento deste tema em suas matérias obrigatórias. Este comportamento pode ser derivado de uma maior exposição do tema pela mídia brasileira e internacional devido aos problemas ambientais enfrentados pelo planeta. Além das freqüentes publicidades "socioambientais" feita por grandes empresas brasileiras.

Foi utilizada uma pesquisa quantitativa descritiva com aplicação de 85 questionários. Porém, 78 questionários foram válidos, o que represente $83 \%$ do total de alunos formandos. Do total de pesquisados aproximadamente $60 \%$ estão se formando em 8 ou 9 semestres e $99 \%$ já tiveram experiência com estágio ou trabalho.

Após a aplicação, tabulação e analise de dados é possível afirmar que o presente estudo alcançou seu objetivo geral bem como os objetivos específicos. Pois foi possível analisar a importância atribuída pelos alunos de administração à gestão ambiental. Percebeuse que os alunos atribuem uma grande importância ao assunto, bem como ao seu aprendizado no curso de administração, pois a média geral para os estes dois macro temas foi de 3,80 em uma escala Likert de 1 a 5.

Todavia observou-se que o interesse futuro, no âmbito profissional, dos alunos sobre gestão ambiental é muito baixo. Prova disso constata-se por dados da pesquisa como dos 
33,3\% dos entrevistados que trabalharam diretamente com gestão ambiental nenhum pretende fazer pós-graduação na área.

É interessante observar também que mesmo sem uma disciplina no currículo do curso os alunos conseguem evidenciar a importância do construto. E indo além mesmo sem terem recebido a formação acadêmica em gestão ambiental os pesquisados atribuem grande importância para o papel de formação do curso de administração acerca de gestão ambiental. Evidenciando assim que o aprendizado do aluno não encontrasse somente na academia mas também no mercado de trabalho e em diversas fontes de informações disponível no mundo contemporânea.

$\mathrm{Na}$ presente pesquisa os resultados se assemelham aos presentes na literatura. O que vai ao encontro com a corrente de pesquisas realizadas neste âmbito. Além disso, é inerente à pesquisa sugerir a criação de uma ou mais disciplinas que abordem o tema gestão ambiental. Visto que é um tema atual e que possivelmente será cobrado dos futuros administradores no mercado de trabalho.

A pesquisa realizada neste estudo teve limitações. Primeiramente, pela amostra ter sido somente de alunos formandos e de uma única instituição de ensino superior. Somando-se a isto o fato desta instituição ser uma universidade pública federal e única na cidade onde a pesquisa foi realizada.

A realização deste estudo permite que a UnB reflita sobre a atualização dos cursos, em destaque o de administração, para acompanhamento dos conhecimentos emergentes e necessários para a boa formação dos futuros profissionais formados pela instituição. Todavia, a inclusão de disciplinas que abordam o tema gestão ambiental tornam-se difíceis de adaptarse as matrizes curriculares dos cursos como apontado pela literatura. 


\section{REFERÊNCIAS}

ALMEIDA, Ribeiro Josimar. et. al. Gerenciamento Ambiental. Rio de Janeiro: Thex, 2007.

BARBIERI, José Carlos. Gestão Ambiental Empresarial: Conceitos Modelos e Instrumentos. São Paulo: Saraiva, 2004.

A educação ambiental e a gestão ambiental em cursos de graduação em administração: objetivos, desafios e propostas. Revista de Administração Pública. v. 38, n.6, 2004.

BERNARDES, Rui Otávio, TACHIZAWA, Takeshy, CARVALHO, Ana Barretos, Gestão ambiental. Enfoque estratégico aplicado ao desenvolvimento sustentável, 2. ed. São Paulo: Makron Books, 2004.

BOECHAT, Cláudio Bruzzi; GRASSI, Maria Raquel; FILHO, Raimundo Soares. Estratégias empresariais brasileiras à luz da sustentabilidade. In:Encontro Nacional de Gestão Empresarial e Meio Ambiente-ENGEMA, 8., 2005, Rio de Janeiro.

BRASIL. Constituição (1988). Constituição da República Federativa do Brasil. Brasília, DF.

BRUNDTLAND,Gro Harlem. Areas of environmental action: health, sustainable consumption. Disponível em: http://www.unep.org/women_env/w_details.asp?w_id=43. Acessado em: 26 de março de 2009.

BRUNS, Giovana Baggio de, Afinal o que é Gestão Ambiental. Ambiente Brasil. [S.d]. Disponível

em:http://ambientes.ambientebrasil.com.br/gestao/artigos/afinal,_o_que_e_gestao_ambien tal\%3F.html. Acesso em: 29 de março de 2009.

CONAMA - Conselho Nacional do Meio Ambiente. Resolução n 001, de 23 de janeiro de 1986, publicado no D. O U. de 17.2.86. <www.mma.gov.br/por/conama/res/res/86/res0186.html> Acesso em: 29 março de 2009.

COSTA, José Costa da; OLIVEIRA, Leonel Gois Lima; CAVALCANTE, Elizabeth Silva; MUZZIO, Henrique. A gestão ambiental na formação em administração: uma análise da perspectiva dos alunos. In:Encontro Nacional de Gestão Empresarial e Meio Ambiente-ENGEMA, 10., 2008, Porto Alegre.

COSTA, José Costa da; OLIVEIRA, Leonel Gois Lima. A gestão ambiental no curso de administração: uma analise da perspectivas dos professores. Revista Eletrônica de Gestão. v.1, n. 1, p. 59-73, Set/Dez 2008. 
CORAZZA, Rosana I. Gestão Ambiental e mudanças da estrutura organizacional. RAE - eletrônica, v. 2, n. 2, p. 119-30, jul./dez. 2003.

CROGNALE, Gabriele. Environmental management strategies: the 21st century perspective. [S.1]: Prentice Hall PTR, 1999. v.5.

DIAS, Sylmara Lopes Franceline Gonçalves. et. al. Consciência Ambiental: um estudo exploratório sobre suas implicações para o ensino de administração.RAE Eletrônica, v. 8, n. X, 2009.

DONAIRE, D. Considerações sobre a influencia da variável ambiental na empresa. Revista de Administração de Empresas, v.34, n. 2, p. 78-77, mar./ abr, 1994.

DYLLICK et al. Guia da Série de Normas ISO 14001: Sistema de Gestão Ambiental. Tradução de Beate Frank. Blumenau: Edifurb, 2000.

.Gestão Ambiental na Empresa. 2. ed. São Paulo: Atlas, 1999.

FERREIRA, Denize Demarche Minatti; FERREIRA, Luiz Felipe. O ensino de gestão ambiental nos cursos de administração de empresas nas IES (instituições de ensino superior) do estado de Santa Catarina: um estudo exploratório. In: CONGRESSO NACIONAL DE EXÊLENCIA EM GESTÃO, 4., 2008, Niterói.

SOARES, Raimundo Filho. Ritual de passagem: A educação de lideranças para a sustentabilidade. Caderno de Idéias. Ano. 6, n. 6, 2006.

FREY, Márcia Rosane; WITTMANN, Milton Luiz. Gestão ambiental e Desenvolvimento regional:uma análise da indústria fumageira. Revista Euro, v. 32, n. 96, p. 99-115, Santiago do Chile, 2006.

INDG. Gestão Ambiental: Definição. São Paulo. [S.1] 2009. Disponível em: http://www.indg.com.br/iso14000/definicao.asp. Acessado em : 24 de março de 2009.

JABBOUR, Charbel José Chiappetta; SANTOS, Fenrnado César Almada; BARBIERI, José Carlos. Gestão ambiental empresarial: um levantamento da produção científica brasileira divulgada em periódicos da área de administração entre 1996 e 2005. Revista de Administração Contemporânea, v.12, n. 3, p. 789-715, 2008.

KEIMERT, Tânia; KARRUZ, Ana Paula. Qualidade de vida: observatórios, experiências e metodologias. São Paulo: Annablume, 2002.

KHOR, Matin. Confrontação de Paradigmas. Tradução de Anna Carolina Mendes da Silva. Insituto Brasil PNUMA, [S.d]. Disponível em: http://www.brasilpnuma.org.br/pordentro/artigos_029.htm. Acesso em: 30 de março de 2009.

KRIEGER, Maria da Graça. et al. Glossário de gestão ambiental. São Paulo: Disal, 2006. 
MAIMON, Dália. Passaporte Verde Gestão ambiental e competitividade. Rio de Janeiro: Qualitymark, 1996.

MENEGAT, Rualdo; ALMEIDA, Gerson. et al. Desenvolvimento sustentável e gestão ambiental nas cidades: estratégias a partir de Porto Alegre. Porto Alegre: Editora da UFRGS, 2004.

PORTER, M. E.; KRAMER, M. R. Estratégia e sociedade: o elo entre vantagem competitiva responsabilidade empresarial social. Harvard Business Review, n. 12, 2006.

Procuradoria Geral da República - PGR. O que é gestão ambiental. Brasília. [S.1] 2009. Disponível em: http://pga.pgr.mpf.gov.br/pga/gestao/que-e-ga/o-que-e-gestao-ambiental. Acessado em: 24 de março de 2009.

SACHS, Ignacy. Desenvolvimento includente,sustentável sustentado. Rio de Janeiro: Garamond, 2008.

. Estratégias de transição para o século XXI:Desenvolvimento e meio ambiente. São Paulo:Studio Nobel, Fundap, 1993.

SILVA, Leilianne Michelle Trindade da; SILVA, Marcos Paulo da; ENDERS, Wayne Thomas. Gestão ambiental e desempenho organizacional: um estudo de suas relações no setor hoteleiro. In: Encontro Anual da Associação Nacional dos Cursos de PósGraduação em Administração. 30., 2006, Salvador. Anais eletrônicos... Salvador: ANPAD, 2006.

TACHIZAWA, Takeshy. Gestão Ambiental e Responsabilidade Social Corporativa: Estratégias de negócio focadas na realidade brasileira. 5 ed. rev. São Paulo: Atlas, 2008.

VAN BELLEN, Hans Michael. Desenvolvimento sustentável: uma descrição das principais ferramentas de avaliação. Ambiente \& Sociedade, vol.7, n.1, pp. 67-87. 2004.

VITERBO JUNIOR, Ênio. Sistema integrado de gestão ambiental: como implementar um sistema de gestão que atenda à norma ISO 14001, a partir de um sistema baseado no norma ISO 9000. São Paulo: Aquariana, 1998.

VALLE, Cyro Eyer. Qualidade Ambiental ISO 14000. Editora SENAC. 5a. Edição revista e ampliada, São Paulo, 2002.

WRIGHT, James; SPERS, Renata Giovinazzo; BENEDETE, Antonio Thiago. Delphi Profuturo prospecta carreiras do future e tendências do empreendedorismo para 2020. Fia/Profuturo, 09 de abril de 2009. Disponível em: www.fia.com.br/profututo. 


\section{APÊNDICES}

\section{Anexo A - Questionário}

\section{QUESTIONÁRIO}

Prezada(o) Colega,

Esta pesquisa tem por objetivo identificar a percepção de alunos do Curso de Graduação em Administração da Universidade de Brasília em relação a gestão ambiental e tem como finalidade a elaboração de trabalho de conclusão de curso. Peço sua colaboração respondendo as questões que seguem. Sua participação na pesquisa é muito importante para o meu trabalho e os dados serão analisados de forma agregada, mantendo-se o anonimato dos participantes.

1. Em quantos períodos letivos você esta se formando?

2. Você trabalha/estagia atualmente?

a) [ ] Sim (passe para a questão 4)

b) [ ] Não

3. Você já trabalhou/estagiou?

a) [ ] $\mathrm{Sim}$

b) [ ] Não (passe para a questão 6)

4. Você trabalha/ trabalhou, realizou alguma atividade associada a gestão ambiental?

a) $[\quad] \mathrm{Sim}$

b) [ ] Não (passe para a questão 6)

5. Caso sim, informe quais?

a) [ ] Meu trabalho envolve gestão ambiental

b) [ ] Projeto na faculdade

c) [ ] Trabalhos para empresas especializadas em gestão ambiental

d) [ ] Atividades juntos a Organizações Não Governamentais (ONGs) da área

e) [ ] Outros

6. No seu entendimento, o tema gestão ambiental deveria ser?

a) [ ] Tratado somente em nível de pós-graduação

b) [ ] Uma disciplina dos currículos de graduação em Administração 
c) [ ] Um curso independente

d) [ ] Analisado com conteúdo interdisciplinar (várias disciplinas) de cursos de Administração

e) [ ] Tratado como Atividade Complementar

f) $[\quad]$ Outros

7. A seguir há uma série de afirmativas sobre a IMPORTÂNCIA DO CONHECIMENTO em gestão ambiental. Peço que você assinale um número nas colunas da direita. Quanto mais próxima do número '1'for a sua resposta menos você concorda com a afirmativa e quanto mais próxima do número '5' mais você concorda. Não há respostas certas ou erradas. O que importa é o seu pontos de vista.

\begin{tabular}{|l|l|l|l|l}
\hline 1 - Discordo totalmente & & & & 5 - Concordo totalmente \\
\hline
\end{tabular}

\begin{tabular}{|c|c|c|c|c|c|}
\hline $\begin{array}{l}\text { O aprendizado sobre gestão ambiental é um assunto de grande importância para a } \\
\text { formação em Administração }\end{array}$ & 1 & 2 & 3 & 4 & 5 \\
\hline Uma boa formação em Administração passa pela formação em gestão ambiental & 1 & 2 & 3 & 4 & 5 \\
\hline $\begin{array}{l}\text { Graduandos em Administração devem saber como resolver problemas de gestão } \\
\text { ambiental }\end{array}$ & 1 & 2 & 3 & 4 & 5 \\
\hline $\begin{array}{l}\text { Escolas de Administração deveriam oferecer oportunidades para que os estudantes } \\
\text { aumentem sua compreensão sobre gestão ambiental }\end{array}$ & 1 & 2 & 3 & 4 & 5 \\
\hline $\begin{array}{l}\text { Escolas de Administração deveriam incentivar estudantes para se envolverem em } \\
\text { projetos ambientais }\end{array}$ & 1 & 2 & 3 & 4 & 5 \\
\hline
\end{tabular}

8. A seguir, há um conjunto de afirmativas sobre o PAPEL DOS CURSOS de Administração em relação a gestão ambiental. Peço que você assinale um número nas colunas da direita. Quanto mais próxima do número '1'for a sua resposta menos você concorda com a afirmativa e quanto mais próxima do número '5' mais você concorda. Não há respostas certas ou erradas. O que importa é o seu pontos de vista.

\begin{tabular}{|l|l|l|l|l|}
\hline 1 - Discordo totalmente & & & 5 - Concordo totalmente \\
\hline
\end{tabular}

\begin{tabular}{|l|l|l|l|l|l|}
\hline Cursos de Administração deveriam envolver os estudantes em assuntos ambientais & 1 & 2 & 3 & 4 & 5 \\
\hline $\begin{array}{l}\text { Cursos de Administração deveriam preparar estudantes para ser líderes de projetos } \\
\text { ambientais }\end{array}$ & 1 & 2 & 3 & 4 & 5 \\
\hline $\begin{array}{l}\text { Cursos de Administração deveriam avaliar nos alunos conhecimentos sobre } \\
\text { responsabilidade ambiental }\end{array}$ & 1 & 3 & 4 & 5 \\
\hline $\begin{array}{l}\text { Cursos de Administração deveriam incluir no currículo conteúdos/disciplinas sobre } \\
\text { gestão ambiental }\end{array}$ & 2 & 3 & 4 & 5 \\
\hline $\begin{array}{l}\text { Cursos de Administração deveriam incluir tópicos nas várias disciplinas sobre } \\
\text { responsabilidade ambiental }\end{array}$ & 2 & 3 & 4 & 5 \\
\hline
\end{tabular}

9. Agora gostaria que você respondesse as questões a seguir sobre suas INTENÇÕES FUTURAS em relação a gestão ambiental. Na escala, os números indicam:

\begin{tabular}{|c|c|c|c|c|c|}
\hline - muito improvável & 2 -improvável & 3 -pouco provável & 4 -bastante provável & 5 -seguramente \\
\hline
\end{tabular}

\begin{tabular}{|c|c|c|c|c|c|}
\hline Probabilidade de fazer cursos diversos na área de gestão ambiental & 1 & 2 & 3 & 4 & 5 \\
\hline Probabilidade de me envolver em projetos ambientais & 1 & 2 & 3 & 4 & 5 \\
\hline Probabilidade de fazer uma pós-graduação em gestão ambiental & 1 & 2 & 3 & 4 & 5 \\
\hline Probabilidade de trabalhar como gestor ambiental & 1 & 2 & 3 & 4 & 5 \\
\hline
\end{tabular}


10. Você cursou alguma disciplina que abordou o tema Gestão ambiental?

a) $[\mathrm{Sim}$

b) [ ] Não

11. Qual a sua principal área de interesse em administração?

a) [ ] Finanças

b) [ ] Marketing

c) [ ] Gestão de pessoas e relações de trabalho

d) [ ] Gestão de operações e logística

e) [ ] Estratégia em organizações

f) [ ] Gestão de tecnologia e informação

g) [ ] Administração pública / Gestão Social

h) [ ] Administração da Informação

12. Qual a sua idade?
a) [ ] Até 21 anos
b) [ ] Acima de 21 até 24 anos
c) [ ] Acima de 24 até 27 anos
d) [ ] Acima de 27 até 30 anos
e) [ ] Acima de 30 anos

13. Qual seu sexo?

a) [ ] Masculino

b) [ ] Feminino

14. Qual o seu estado civil?

a) [ ] Solteiro(a)/vive só

b) [ ] Casado(a)/vive com alguém

15. Qual a sua renda familiar mensal?
a) [ ] Até $\mathrm{R} \$ 1000,00$
b) [ ] Acima de R \$ 1000,00 até R $\$ 2000,00$
c) [ ] Acima de $\mathrm{R} \$ 2000,00$ até $\mathrm{R} \$ 3000,00$
d) [ ] Acima de $\mathrm{R} \$ 3000,00$ até $\mathrm{R} \$ 4000,00$
e) [ ] Acima de $\mathrm{R} \$ 4000,00$ 